\title{
Domestic Violence as a Crime Against the State: The Need for Mandatory Arrest in California
}

\author{
Machaela M. Hoctor $\dagger$
}

Despite the fact that domestic violence is a crime, law enforcement officers often fail to arrest batterers, occasionally with lethal consequences. This suggests that criminalization is an inadequate response to domestic violence unless legislators also enact laws to facilitate arrest. Although some states have made needed reforms in this area, California has lagged behind the national trend. This Comment proposes that California enhance law enforcement's response to domestic violence by abolishing the warrant requirement for all misdemeanor domestic assaults not observed by an officer and enacting a mandatory arrest law targeting the primary physical aggressor in domestic assaults. The author contends that such legislative measures are needed to lay an effective foundation for a coordinated community response that will provide better protection for victims of domestic violence.

\section{INTRODUCTION}

"She wanted him arrested, but the police wouldn't do anything."

"He got essentially no consequences. He's never been given any consequences... for anything that he's done. So it just sort of systematically lets him get further and further out on the

Copyright $\odot 1997$ California Law Review, Inc.

$\dagger$ B.A. 1993, University of Wisconsin at Madison; J.D. candidate 1997, Boalt Hall School of Law, University of California, Berkeley. I would like to thank Susan Breall, Tess Meuer, Nancy Lemon, and Joan Zorza for their insight, energy, and ideas. Special thanks to Tom Ginsburg, Dale Freeman, Tony Aquilina, Sherri Sokeland, Sean Anderson, and all the editors and members of the California Law Review for their hard work and commitment. This Comment is dedicated to Tony Wolfram, whose faith, support, and encouragement made this effort possible.

1. Ann Jones, Next Time She'll Be Dead: Battering \& How to Stop It 41 (1994) (footnote omitted) (referring to the police response to the numerous pleas of Elizabeth Croff to arrest her estranged husband, William Croff, for his repeated assaults, threats, and violations of a protective order). William Croff shot and killed Elizabeth in 1988. See id. 
edge, believing that he's going to be able to do anything he wants."2

Law enforcement officials often fail to arrest and prosecute batterers in domestic violence situations. ${ }^{3}$ Inadequate police response can be attributed, at least in part, to insufficient state laws governing arrest in domestic violence incidents. ${ }^{4}$ Many state legislatures have attempted to respond to this problem with statutory changes, including allowing warrantless arrest for misdemeanor offenses not directly observed by a police officer ${ }^{5}$ and providing for mandatory arrest of the primary physical aggressor in a domestic assault. ${ }^{6}$ Furthermore, several cities have implemented mandatory arrest policies even though their states have not

2. Id. at 39 (referring to the criminal justice system's response to the repeated assaults, threats, kidnappings, and eventual murder of Pamela Guenther in 1987 by her husband, David Guenther).

3. The recent homicides of two women in California demonstrate law enforcement's failure to arrest batterers, even when they have violated valid restraining orders. In August 1996, Nancy Lynch of Hayward, California, was murdered by her ex-boyfriend, Bruce Hammel. Yumi Wilson, When Court Order Isn't Enough, S.F. ChroN., Sept. 20, 1996, at A1. In the veeks prior to her murder, Nancy reported that Hammel violated a restraining order she had against him several times, yet the police took no action. See id. On April 15, 1996, Maria Teresa Macias was murdered by her husband, Avelino Macias, on the steps of her employer's home. Tyra Lucile Mead, State 10 Investigate Sonoma Slaying, S.F. CHRON., May 27, 1996, at A15. Maria had obtained a restraining order against her husband in January, 1996, and her diary reflects that she contacted the Sonoma County Sheriff's Office 18 times to report her husband's continuing violations of the order. George Snyder, Sonoma Sheriff Criticized in Domestic Abuse Death, S.F. ChroN., May 24, 1996, at A17. Again, the officers took no action. See id.

4. In this Comment, the terms "domestic violence" and "domestic abuse" are used interchangeably to refer to assaults involving persons who have an ongoing or a prior intimate relationship. Although "dating violence" is prevalent throughout the juvenile community, the relevant California Penal Code sections only apply to adults. However, these sections are ripe for change. See Kathryn E. Suarez, Comment, Teenage Dating Violence: The Need for Expanded Awareness and Legislation, 82 CALIF. L. REV. 423, 449-52 (1994).

5. See, e.g., ARIz. Rev. Stat. ANN. § 13-3601 (West Supp. 1996); Fla. STAT. ANN. § 901.15 (West 1996); Mass. Gen. Laws ANN. ch. 276, § 28 (West Supp. 1996); MinN. STAt. ANN. $§ 629.341$ (West Supp. 1994); Ohio Rev. Code ANN. §2935.03 (Banks-Baldwin 1996); UTAH Code ANN. § 30-6-8(2) (1993); see also Nancy James, Domestic Violence: A History of Arrest Policies and a Survey of Modern Laws, 28 FAM. L.Q. 509, 513 (1994).

Such a scheme, currently used in many states, has never been held to violate the Fourth Amendment. See William A. Schroeder, Warrantless Misdemeanor Arrests and the Fourth Amendment, 58 Mo. L. REv. 771, 785-87, 794-96 (1993). Under the Fourth Amendment, misdemeanor arrests are constitutional if an officer has probable cause to believe that a suspect has committed a crime. See $i d$. at 802 . The requirement that an officer must observe a misdemeanor offense to make a warrantless arrest stems from common law doctrine. See id. at 788-89. Many states have abandoned this common law rule for certain crimes in light of the overriding public policy concerns that justify arrest without officer observance in these cases. See id. at 831-32.

6. See, e.g., Conn. Gen. Stat. ANN. \& 46b-38b (West Supp. 1996); ME. Rev. Stat. ANn. tit. 19, § 770(5) (West Supp. 1995); WIS. STAT. ANN. § 968.075(2) (West Supp. 1994). Although several states mandate arrest only for violations of restraining orders, the author does not consider this to be a true mandatory arrest scheme. See, e.g., CAL. PENAL, Code § 13701 (West Supp. 1996); N.C. GeN. STAT. $\S 50 B-4$ (1995). These laws do, however, represent a step in the right direction. 
enacted mandatory arrest laws. ${ }^{7}$ These states and cities have discovered that reconceptualizing domestic violence as a crime against the state through mandatory arrest addresses many of the problems victims of domestic violence and law enforcement personnel face in a purely discretionary arrest system.

The importance of eradicating domestic abuse in our society cannot be overstated. Domestic violence is the leading cause of injury to women in the United States. ${ }^{8}$ Almost one-third of female homicide victims nationwide are killed by current or former husbands or boyfriends. ${ }^{9}$ Domestic battering accounts for twenty-six percent of suicide attempts by women. ${ }^{10}$ More than half of all American couples experience physical violence between the partners at some point during the course of their relationship." However, women separated from their spouses are approximately twenty-five times more likely to experience domestic violence than married women who are not separated from their

7. See, e.g., Sarah Mausolff Buel, Recent Developments, Mandatory Arrest for Domestic Violence, 11 HARV. WOMEN's E.J. 213, 215 (1988) (reporting that police departments in Concord, New Hampshire; Duluth, Minnesota; Pittsburgh, Pennsylvania; Charleston, South Carolina; and Newport News, Virginia have mandatory arrest policies in effect). San Francisco and San Diego also enforce mandatory arrest policies.

8. See Susan A. MacManus \& Nikki R. Van Hightower, Limits of State Constitutional Guarantees: Lessons From Efforts to Implement Domestic Violence Policies, 49 PuB. ADMIN. REV. 269,269 (1989). In the vast majority of reported incidents, domestic violence is perpetrated by men against women. See Bureau of Justice Statistics, U.S. Dep'T of Justice, Report to the Nation on Crime and Justice: The Data 21 (1983) [hereinafter The Data]; Anthony Bouza, Responding to Domestic Violence, in Woman BatTerung: Policy Responses 191, 191-92 (Michael Steinman ed., 1991) [hereinafter Woman BatTERING]. But see Armin A. Brott, Who is Being Hurt? Men Also Leave the House with Bruises, Ft. Worth Star-Telegram, Oct. 15, 1995, at 5 (questioning the validity of statistics that show women are more likely than men to be victims of abuse). While some question the gender breakdown of incidents of domestic violence, female victims are much more likely to suffer serious physical injury than male victims. This is reflected in domestic violence homicide statistics that capture the ultimate escalation of the cycle of violence. See Lenore E. Walker, The Battered Woman 55-70 (1979) (detailing the phases of the cycle of violence in battering). Although $28 \%$ of all women killed in America in 1992 were murdered by a current or former partner, just over 3\% of men were killed as a result of domestic violence. See Ronet Bachman \& Linda E. Saltzman, Violence Against Women: Estimates from the Redesigned Survey, in Office of Justice Programs, U.S. Dep't of Justice, Bureau of Justice Statistics Special Report: National Crime Victimization SuRvey 4 (1995). Of course, domestic violence also occurs in gay and lesbian relationships. See infra Part 1V. This Comment refers to victims as "she" and batterers as "he" for consistency and convenience.

9. See Bachman \& Saltzman, supra note 8, at 4.

10. See Evan Stark \& Anne H. Flitcraft, Spouse Abuse, in Violence in AMerica: A Public Health Approach 121, 141 (Mark L. Rosenberg \& Mary Ann Fenley eds., 1991).

11. See Scott L. Feld \& Murray A. Straus, Escalation and Desistance of Wife Assault in Marriage, 27 Criminology 141, 141 (1989); see also Roger LANGLEY \& Richard C. LeVy, WifE Beating: The Silent Crisis 12 (1977) (reporting studies showing that at least half of all marriages involved at least one incident of domestic violence). 
husbands. ${ }^{12}$ The numbers are staggering, yet the FBI estimates that only one in ten domestic violence incidents is reported. ${ }^{13}$

Society pays a high price for this epidemic of abuse. More than $1,400,000$ visits to American emergency rooms per year result from domestic violence. ${ }^{14}$ The American Medical Association reports that domestic violence accounts for at least 21,000 hospitalizations, 99,800 days in the hospital, and 39,000 visits to personal physicians annually in the United States. ${ }^{15}$ In fact, women are injured more often and more severely by domestic abuse than they are by stranger assaults. ${ }^{16}$ Domestic abuse forces many battered women to miss days from work. ${ }^{17}$ In addition to this lost time, battered women are often harassed at work by their abusers and have trouble performing their jobs or lose their jobs altogether because of the abuse. ${ }^{18}$ In total, domestic violence costs employers between three and thirteen billion dollars annually. ${ }^{19}$

Society pays additional high costs for law enforcement as a result of domestic violence. Police departments receive more calls reporting domestic abuse than any other type of crime,$^{20}$ and response to these calls accounts for one-third of all police time. ${ }^{21}$ New York City paid at least forty-one million dollars in police, court, and detention costs in 1989 for arrests stemming from domestic violence incidents, not to mention the cost for incidents not resulting in arrest. ${ }^{22}$

Society pays for domestic violence in more subtle ways as well. Up to half of all homeless women and children have taken to the streets to escape abuse at home. ${ }^{23}$ Batterers destroy an average of $\$ 10,000$ in property belonging to battered women and their families before these

12. See Bachman \& Saltzman, supra note 8, at 4.

13. See Sari Horwitz, D.C. Police to Make Arrests in Domestic Violence Disputes; Cases to Be Treated as Criminal Offenses, WASH. POST, June 3, 1987, at A1, A7.

14. See Joan Zorza, Woman Battering: High Costs and the State of the Law, 28 Clearinghouse Rev. 383, 383 (1994).

15. See Harris Meyer, The Billion Dollar Epidemic, AM. Med. NEws, Jan. 6, 1992, at 7.

16. See Bachman \& Saltzman, supra note 8 , at 5 .

17. See Zorza, supra note 14 , at 384-85.

18. See id.

19. See id. at 385 .

20. See Susanne M. Browne, Note, Due Process and Equal Protection Challenges to the Inadequate Response of the Police in Domestic Violence Situations, 68 S. CAL. L. REv. 1295, 1298 (1995).

21. See Zorza, supra note 14 , at 385 .

22. See id. Despite this high price tag, however, current police responses are largely ineffective. A study of homicides in New York City from 1990 to 1994 revealed that, in the cases in which the killer's relationship to the victim could be ascertained, nearly half of the women killed were murdered by current or former boyfriends or husbands. See Pam Belluck, $A$ Woman's Killer Is Likely to Be Her Partner, A Study Finds, N.Y. Times, March 31, 1997, at A12.

23. See Joan Zorza, Woman Battering: A Major Cause of Homelessness, 25 Clearinghouse REv. 421, 421-22 (1991). 
women seek refuge in a shelter. ${ }^{24}$ Society also pays the expenses of many children in foster care-children who would have been able to stay with their mothers had their mothers not become victims of abuse. ${ }^{25}$ Furthermore, a boy who watches his father assault his mother is more likely to become a batterer than if his father had abused him instead. ${ }^{26}$ More than sixty percent of all males convicted of murder in the United States between the ages of eleven and twenty were convicted for killing the man who abused their mother. ${ }^{27}$

The criminal justice system has only recently attempted to address this epidemic of domestic violence. In the past, most police departments had an official policy of avoiding arrest whenever possible in domestic abuse incidents and instead encouraged the separation of the parties, usually by instructing the batterer to take a walk around the block. ${ }^{28}$ It is only within the last fifteen years that state legislatures have enacted statutory changes to facilitate the arrest of perpetrators of domestic violence and to encourage their prosecution. ${ }^{29}$

Although many states have made significant statutory changes in order to provide for and facilitate arrests in dounestic violence situations, California lags behind this national trend. California was one of the last states to continue to allow for a warrantless misdenneanor arrest only when a domestic violence offense was committed in an officer's presence. $^{30}$ Although the legislature changed the law in 1996 to allow for warrantless arrests of some misdemeanor domestic violence offenders, a warrant is still required to arrest many domestic abusers. ${ }^{31}$ Moreover, enabling warrantless arrest has not guaranteed that officers will make

24. See Ann Campbell White, What You Didn't Learn in Law School: Family Law and Domestic Violence, FLA. BAR. J., Oct. 1994, at 38, 40.

25. See Zorza, supra note 14 , at 384 .

26. See id.; see also Naomi R. Cahn, Civil Images of Battered Women: The Impact of Domestic Violence on Child Custody Decisions, 44 VAND. L. REv. 1041, 1055-58 (1991) (explaining the negative effects of domestic violence on children who witness such abuse).

27. See Sarah M. Buel, The Dynamics of Domestic Violence Cases in the United States: An Overview, in ABA Sec. of Crim. Just. \& Div. for Prof. Educ., Defending BatTered Women in Criminal Cases 12 (1992).

28. See Developments in the Law-Legal Responses to Domestic Violence, 106 HARv. L. REv. 1498, 1535-36 (1993) [hereinafter Developments].

29. See id. at 1535-38; see also Buel, supra note 7, at 214-15.

30. Cf. Joan Zorza, The Criminal Law of Misdemeanor Domestic Violence, 1970-1990, $85 \mathrm{~J}$. Crim. L. \& CRiminology 46, 62-63 (1992) (including California as a state that does not require a warrant for a misdemeanor domestic violence assault). This classification is most likely due to the liberal definition in Califomia Penal Code section 273.5 of "traumatic injury," described later in the text, which, in effect, allows officers to treat as felonies certain crimes of domestic violence that officers normally would treat as misdemeanors. California did not authorize warrantless arrests for some misdemeanor domestic violence offenses until 1996. See infra note 31.

31. See Cal. Penal Code $\$ 836$ (d) (West Supp. 1997) (amending Cal. Penal Code $\$ 836(d)$ (West 1996)). Effective January 1, 1997, Penal Code $\S 836$ allows officers to make a warrantless arrest when they have reasonable cause to believe an offender has assaulted his or her spouse, cohabitant, or a person with whom he or she has a child in common. See id. 
arrests in domestic violence situations. California Penal Code $\S 273.5,{ }^{32}$ which makes some domestic assaults a felony, thereby enabling warrantless arrest, has frequently been interpreted by law enforcement agencies to exempt many domestic abuse assaults. Consequently, we need legislative reform to provide adequate protection to all victims of domestic violence in California.

This Comment details the need for such change in California's laws. Specifically, it argues for the abolition of the warrant requirement for all misdemeanor domestic violence assaults not observed by a police officer and for the enactment of a mandatory arrest law for the primary physical aggressor in domestic assaults. It discusses and refutes the arguments against inandatory arrest statutes, and addresses the major arrest studies advanced by both supporters and opponents of mandatory arrest laws.

Part I of this Comment discusses traditional police responses to domestic assaults and traces the changes in law enforcement's approach to domestic abuse, as well as the court's reception of battered women's claims against police for inadequate protection. Part II demonstrates California's need for warrantless arrest in all misdemeanor domestic violence assaults and for a mandatory arrest statute to protect victims of domestic violence and to eliminate discrimination in current police practices. Part III proposes a statutory remedy aimed at meeting this need. Part IV addresses the concerns of opponents to mandatory arrest schemes and concludes that with proper training, statutory language, and close scrntiny by advocates, the public, and the courts, mandatory arrest can be effective. Finally, Part V explains how mandatory arrest is just one piece of the comprehensive, coordinated community response needed to effectively combat domestic violence. By making domestic violence a crime against the state, mandatory arrest will take the criminal justice system's focus off the victim and place it where it belongs-on the person who has violated the laws of California. Mandatory arrest, as part of a coordinated community response, will provide just punishment for batterers, greater awareness to society in general, and, most importantly, windows of opportunity for victims of domestic abuse to establish lives free from violence.

32. Cal. Penal Code $\S 273.5$ (a) (West Supp. 1996), provides that

[a]ny person who willfully inflicts upon his or her spouse, or any person who willfully inflicts upon any person with whom he or she is cohabiting, or any person who willfully inflicts upon any person who is the mother or father of his or her child, corporal injury resulting in a traumatic condition, is guilty of a felony ....

"Traumatic condition" is liberally defined in $\$ 273.5(\mathrm{c})$ as "a condition of the body, such as a wound or external or internal injury, whether of a minor or serious nature, caused by a physical force." 
I

History of Police Response to Domestic Violence

\section{A. Non-Arrest Policies for Domestic Abuse}

Despite the prevalence of domestic violence, police in the United States have generally been indifferent to domestic abuse crimes, giving them very low priority. ${ }^{33}$ Police treatment of domestic abuse calls has traditionally consisted of not responding at all, purposefully delaying response, even for several hours, or, when officers did respond, attempting to talk to or separate the parties so they could "cool off."34 These inadequate responses to oftentimes severe assaults were not attributable to rogue officers. To the contrary, throughout the 1960s, 1970s and early 1980s, law enforcement officers were taught that domestic violence was a private matter between the parties in which the state should not interfere. ${ }^{35}$ In conformity with this policy, arrests were virtually never made in domestic violence situations, and, when an arrest was made, it was usually because the abuser was belligerent or violent to the officers themselves. ${ }^{36}$

When officers did respond to a domestic violence call, they usually attempted to mediate the dispute. ${ }^{37}$ This "mediation" consisted of a variety of approaches, including attempts by officers to convince the parties to reconcile immediately at the scene or to use formal alternative dispute resolution programs. ${ }^{38}$ Police officers were trained to "separate the parties in a domestic 'dispute,' calm them down, generate discussion of the problem, and refer the parties to [couples'] counseling if necessary. ${ }^{3} 39$

This mediation approach to criminal acts of domestic violence fails adequately to address the dynamics of domestic abuse. The ideology and practice of mediation is based on the resolution of conflicts through negotiation between two equal parties. ${ }^{40}$ This construct is incompatible with the dynamics of domestic violence, where abuse is based not upon "conflict," but upon the need to obtain power and control over another person. ${ }^{41}$ The "conflict," which is often mislabeled the "cause" of the abuse, is actually a situation generated by the abuser as an excuse to

33. See Zorza, supra note 30 , at 47 .

34. See id. at 47-48.

35. See id.; Developments, supra note 28, at 1535-36.

36. See Zorza, supra note 30 , at 52 (citing Eve S. Buzawa \& Carl G. Buzawa, Domestic Violence: The Criminal Response 108 (1990)).

37. See Developments, supra note 28 , at 1535-36.

38. See id.

39. Id. at 1536.

40. See Karla Fischer et al., The Culture of Battering and the Role of Mediation in Domestic Violence Cases, 46 SMU L. REv. 2117, 2161-62 (1993).

41. See id. at 2158 . 
beat his partner. ${ }^{42}$ A history of abuse, intimidation and fear renders any and all attempts to have "negotiations" between "equal" parties hopeless. ${ }^{43}$ Furthermore, the focus of mediation on the future and on the need for both parties to accept responsibility for "their problems" allows the batterer to avoid all responsibility for his behavior and reinforces the victim's belief that she is somehow at fault for her beatings. ${ }^{44}$

While mediation for domestic violence was the informal practice in most police departments, some departments had official non-arrest policies for domestic abuse, as demonstrated by the Oakland, California Police Department's 1975 Training Bulletin on Techniques of Dispute Intervention, which described

[t]he police role in a dispute situation [as] more often that of a mediator and peacemaker than enforcer of the law.... [T] he possibility that ... arrest will only aggravate the dispute or create a serious danger for the arresting officers due to possible efforts to resist arrest ... is most likely when a husband or father is arrested in his home... Normally, officers should adhere to the policy that arrests shall be avoided ... but when one of the parties demands arrest, you should attempt to explain the ramifications of such action (e.g., loss of wages, bail procedures, court appearances) and encourage the parties to reason with each other. $^{45}$

Similarly, the state of Michigan's domestic abuse policy in the 1970s instructed officers to avoid arrest whenever possible by appealing to the complainant's "vanity." 46

In 1984, only ten percent of large city police departments in the United States encouraged officers to make arrests for crimes of domestic violence. ${ }^{47}$ Forty percent of these police departments encouraged mediation, while fifty percent had no policy on domestic violence whatsoever. ${ }^{48}$ The U.S. Attorney General's Task Force on Family Violence identified this failure of law enforcement to arrest for crimes of domestic violence as one of the most serious obstacles to curtailing the epidemic of domestic abuse plaguing the country. ${ }^{49}$

42. See id.

43. See id. at 2161-62.

44. See id. at 2160-63.

45. Zorza, supra note 30, at 48 (quoting Del Martin, Battered Wives 93-94 (1981)) (alterations in original).

46. MARTIN, supra note 45 , at 93.

47. See Browne, supra note 20 , at 1298.

48. See id.

49. See Att'y Gen.'s Task Force on Family Violence, Final Report 16-18 (1984) [hereinafter TASK FORCE]. 


\section{B. Court Challenges to Non-Arrest Policies}

As a result of law enforcement's failure to arrest even those husbands and boyfriends who had committed felony assaults, battered women and their families looked to the courts for protection. They began by filing wrongful death and failure-to-protect actions against municipal police departments. One of the first such lawsuits against the police, Hartzler v. City of San Jose, ${ }^{50}$ occurred in California.

During 1971 and 1972, Ruth Bunnell had called the San Jose Police Department at least twenty times to report violent assaults committed against her and her two daughters by her estranged husband, Mack Bunnell..$^{\text {s1 }}$ However, Mack Bunnell had only been arrested once for assaulting Ruth. ${ }^{52}$

On September 4, 1972, Ruth Bunnell called the police, begging for help because Mack had just called her and told her he was coming to her house to kill her. The department told Ruth to call back when Mack had arrived. When the police arrived forty-five minutes later in response to the call of a neighbor, Mack had already stabbed Ruth to death. ${ }^{53}$ The administrator of Ruth's estate, John Hartzler, filed a wrongful death suit against the San Jose Police Department later that same year. ${ }^{54}$

The California Court of Appeal affirmed the trial court's dismissal of the suit, holding that police departments enjoy absolute, not discretionary, immunity. ${ }^{55}$ The court reasoned that "[a]bsent an indication that the police had induced decedent's reliance on a promise, express or implied, that they would provide her with protection," no "special relationship" could be established. ${ }^{56}$

In the wake of this decision, legal aid attorneys on both sides of the continent decided to try a different approach. In 1976, they filed for declaratory and injunctive relief against the Oakland and New York City police departments in an attempt to force police officers to enforce the law. ${ }^{57}$ The Legal Aid Society of Alameda County in Oakland brought the first suit in October of $1976 .^{58}$ It filed a class action suit against the Chief of the Oakland Police Department, George Hart, on behalf of all female victims of domestic violence, especially African-American

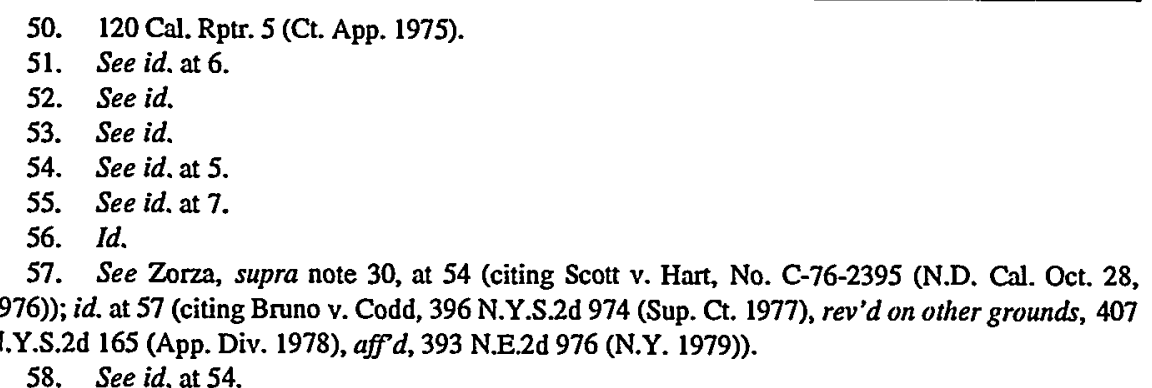


victims. ${ }^{59}$ The named plaintiffs were all African-American women who had called the Oakland police numerous times requesting protection from their husbands, ex-husbands, or boyfriends who were assaulting them..$^{60}$ However, their pleas for help were met with either ineffective police response or no response at all. ${ }^{61}$

The plaintiffs' attorneys made several claims. First, they alleged a denial of equal protection in violation of the Fourteenth Amendment on behalf of the African-American women who had received lesser responses than white victims. ${ }^{62}$ Second, they claimed that the Oakland police had failed to fulfill their duty to arrest for felonious assaults. ${ }^{63}$ Finally, they claimed that the policy that discouraged arrests in domestic violence situations was arbitrary and capricious and deprived the plaintiff class of equal protection of the laws. ${ }^{64}$

It took three years for the case to reach a settlement. ${ }^{65}$

The settlement granted most of the plaintiff's requested relief: the police agreed to a new policy in which they would respond quickly to domestic violence calls. The police also agreed to make an arrest whenever an officer had probable cause to believe that a felonious assault had occurred or that a misdemeanor had been committed in his presence.... The police also agreed not to use the threat of adverse financial consequences for the couple to justify inaction or to urge the victim not to pursue the case. The settlement also required police to inform each battered woman that she had a right to make a citizen's arrest, and required police to help her do so. Officers would thereafter refer victims to supportive agencies for counseling and other assistance. ${ }^{66}$

On the opposite coast, legal aid organizations filed a class action suit against the New York City Police Department less than two months after Hart was filed. ${ }^{67}$ The suit alleged that the police discriminated against married battered women by failing to arrest their assaultive husbands. ${ }^{68}$ Similar to the Oakland Police in Hart, the New York City Police Department entered into a consent judgment with the plaintiffs after losing a motion to dismiss the case. ${ }^{69}$ The judgment provided

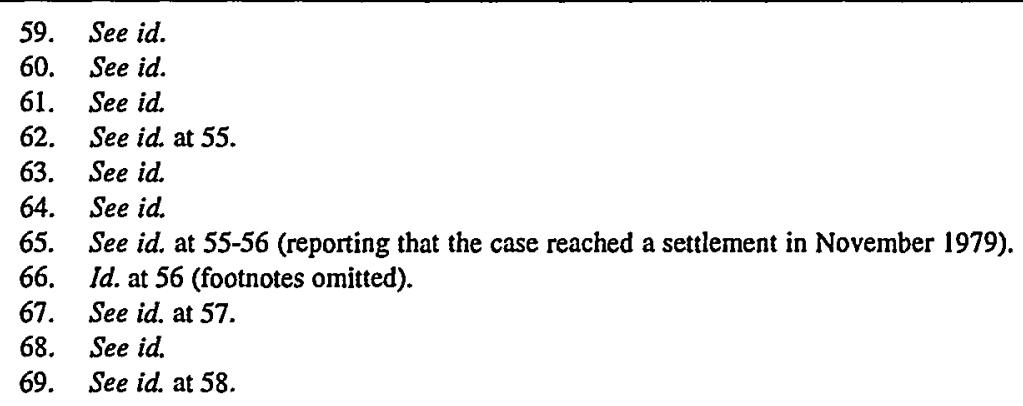


relief similar to that agreed to in Hart, including officer assistance in obtaining medical aid and protective orders for victims of domestic violence. $^{70}$

In the wake of widespread publicity of the Oakland and New York class action suits, police departments all over the country were put on notice that they might be facing expensive legal battles if they failed adequately to protect victims of domestic abuse. Consequently, many departments voluntarily changed their policies and procedures. ${ }^{71}$ Battered women's advocates quickly found that the threat of attorney's fees and damages for victims was a powerful bargaining tool in dealings with wary police departments. ${ }^{72}$

As these suits were being settled in 1977, Oregon became the first state in the country to enact a statute requiring police to arrest every time they had probable cause to believe that a domestic violence assault had been committed ${ }^{73}$ and when they knew or should have known that a protective order had been violated. ${ }^{74}$ The statute read, in part:

when a peace officer is at the scene of a domestic disturbance and has probable cause to believe that an assault has occurred between spouses, former spouses or adult persons related by blood or marriage or persons of opposite sex ${ }^{75}$ residing together or who formerly resided together, or to believe that one such person has placed the other in fear of imminent serious physical injury, the officer shall arrest and take into custody the alleged assailant or potential assailant. ${ }^{76}$

By mid-1983, two-thirds of the states had adopted legislation that allowed officers to make warrantless arrests in misdemeanor domestic violence cases, while six states had mandated arrest for certain crimes of domestic violence. ${ }^{77}$

70. See id. at 58-59.

71. See id. at 59.

72. See id.

73. See Or. Rev. Stat. § 133.055(2) (1977).

74. See OR. Rev. Stat. § 133.310(3) (1977).

75. While this statute obviously only applies to heterosexual domestic violence, domestic abuse also occurs in gay and lesbian relationships. See, e.g., Ruthann Robson, Lavender Bruises: IntraLesbian Violence, Law and Lesbian Legal Theory, 20 GoLDEN GATE U. L. Rev. 567, 570 (1990); Patrick Letellier, Identifying and Treating Battered Gay Men, S.F. MED., Apr. 1994, at 16. Legislation to protect against domestic violence rarely includes gays and lesbians. But see Wis. StaT. ANN. §968.075(1)(a) (West 1994) (defining domestic abuse to include assaults "against an adult with whom the person resides or formerly resided"). In 1994, California amended Penal Code $\S 273.5$ to include crimes of domestic abuse committed against same-sex partners. Compare CAL. Penal Code § 273.5 (West 1993) with Cal. Penal Code \& 273.5 (West 1996).

76. OR. Rev. Stat. \& 133.055(2)(a) (1977).

77. See Joan Zorza, Must We Stop Arresting Batterers?: Analysis and Policy Implications of New Police Domestic Violence Studies, 28 New ENG. L. Rev. 929, 936 (1994). 
In addition, many state legislatures and municipal police departments, still unpersuaded by the plaintiffs' "wins" in the Oakland and New York City suits, were convinced to change their domestic abuse policies by Thurman $v$. City of Torrington. ${ }^{78}$ Tracey Thurman had reported for months to the Torrington Police Department that her estranged husband was beating her, stalking her, and threatening to kill her. The department, however, refused to arrest him. The department's trivialization of Tracey's claims culminated in an officer's late response to her call for help; the officer arrived only after her husband had stabbed her more than twelve times. ${ }^{79}$ In addition, after the officer was on the scene, he passively watched as Tracey's husband jumped on her and broke her neck. ${ }^{80}$

In refusing to grant the defendant's motion to dismiss Tracey's claims, the federal district court found that

[i]f officials have notice of the possibility of attacks on women in domestic relationships or other persons, they are under an affirmative duty to take reasonable measures to protect the personal safety of such persons in the community. Failure to perform this duty would constitute a denial of equal protection of the laws. ${ }^{81}$

The court stressed that a marriage license does not entitle a man to assault or terrorize his wife.

Concomitantly, a police officer may not knowingly refrain from interference in such violence, and may not 'automatically decline to make an arrest simply because the assaulter and his victim are married to each other.' Such inaction on the part of the officer is a denial of the equal protection of the laws. ${ }^{82}$

One year later, in 1985, a jury awarded Tracey Thurman $\$ 2.3$ million in compensatory damages for the Torrington Police Department's failure to provide her with the same protection they would have given a person assaulted by a stranger. ${ }^{83}$ The effect of Thurman echoed throughout the nation. Police departments could now be sure that, at least in some domestic violence cases, large liability awards would be upheld. The Los Angeles Police Department, which faced a class action lawsuit on behalf of battered women alleging discrimination by law enforcement, entered into a consent decree much like the decrees

\footnotetext{
78. 595 F. Supp. 1521 (D. Conn. 1984).

79. See id. at 1525-26.

80. See id.

81. Id. at 1527.

82. Id. at 1528 (quoting Bruno v. Codd, 396 N.Y.S.2d 974 (Sup. Ct. 1977), rev'd on other grounds, 407 N.Y.S.2d 165 (App. Div. 1978), aff'd, 393 N.E.2d 976 (N.Y. 1979)).

83. See JONES, supra note 1, at 52. The city appealed the award, and Thurman later settled out-of-court for $\$ 1.9$ million. Her son was awarded an additional $\$ 300,000$. See id. at $246 \mathrm{n} .10$.
} 
stemming from the Oakland and New York City suits. ${ }^{84}$ As part of the decree, the L.A.P.D. agreed to treat domestic violence cases "as they would treat similar or identical" cases involving violence between strangers and agreed to arrest abusers in felony domestic violence cases. ${ }^{85}$ In addition, Connecticut and other states rushed to adopt new, comprehensive domestic violence laws calling for the arrest of batterers. $^{86}$

\section{Empirical Studies of the Effectiveness of Arrest}

\section{The Minneapolis Experiment}

Thurman was not the only catalyst for changing the behavior and attitudes of the police in the mid-1980s. In 1984, the U.S. National Institute of Justice released the results of the first scientifically controlled experiment to test the effect of arrest on incidents of domestic violence. ${ }^{87}$ The experiment involved 314 incidents of domestic violence. ${ }^{88}$ In responding to these domestic abuse calls, the Minneapolis Police Department used a system of three randomly assigned responses. The suspects were either (1) arrested, if the officers had probable cause to make an arrest, (2) counseled by the officers, or (3) "separated" from the victim with the threat of arrest for future incidents. ${ }^{89}$ During a six-month follow-up period, official police reports differed from victim reports with regard to offender recidivism. According to police reports, approximately thirteen percent of those arrested and twenty-six percent of those removed from the scene had subsequently repeated the violence..$^{00}$ The recidivism of suspects counseled at the scene was statistically indistinguishable from the other two responses. However, victim reports showed that suspects who were counseled had the highest rate of recidivism, while those who were arrested had the lowest. ${ }^{91}$

Data collected from victims who had later been interviewed confirmed that arresting their batterers put the women at a lower risk of repeat abuse than did either of the two other police responses. ${ }^{92}$ Victims

84. See Thomas v. City of Los Angeles, No. CA-000572 (Sup. Ct. Nov. 7, 1985).

85. Id. at Attachment A., 1-3.

86. See, e.g., Conn. Gen. Stat. ANN. § 46b-38b (West Supp. 1993); Wash. Rev. Code ANN. $\S 10.31 .100(2)$ (West Supp. 1994).

87. See Lawrence W. Sherman, The Influence of Criminology on Criminal Law: Evaluating Arrests for Misdemeanor Domestic Violence, 83 J. CRIM. L. \& CRIMINologY 1, 2 (1992); Zorza, supra note 77, at 935.

88. See Sherman, supra note 87 , at 2.

89. See Lawrence W. Sherman \& Richard A. Berk, The Speciflc Deterrent Effects of Arrest for Domestic Assault, 49 AM. Soc. Rev. 261, 263 (1984).

90. See id. at 267.

91. See id.

92. See Zorza, supra note 77 , at 934. 
reported that nineteen percent of arrested batterers, thirty-seven percent of advised batterers, and thirty-three percent of removed batterers reassaulted them after the initial incident. ${ }^{93}$ Thus, arrest was the most effective law enforcement response to crimes of domestic violence according to both official police records and victim interviews. ${ }^{94}$

Citing the Minneapolis experiment, the U.S. Attorney General issued a report recommending that arrest be the standard law enforcement response to cases of misdemeanor domestic violence. ${ }^{95}$ By 1986, just two years after the study's release and the jury award in Thurman, proarrest policies became the most common police policy for misdemeanor domestic assaults. ${ }^{96}$ In 1989, eighty-four percent of urban police agencies reported having mandatory or pro-arrest policies for domestic violence cases. ${ }^{97}$ By 1992, fourteen states and the District of Columbia required the police to arrest upon probable cause that a crime had been committed in a domestic violence situation..$^{98}$ In addition, nineteen states required that an arrest be made if the suspect had violated an order of protection.99

As pro-arrest policies gained popularity, a number of police departments and policy makers began to question whether the techniques used in the Minneapolis experiment were valid and whether its results could be replicated elsewhere. Critics questioned whether the study really demonstrated that arrest had a deterrent effect on domestic violence. ${ }^{100}$ The National Institute of Justice, which funded the initial Minneapolis study, responded by funding six replication experiments in

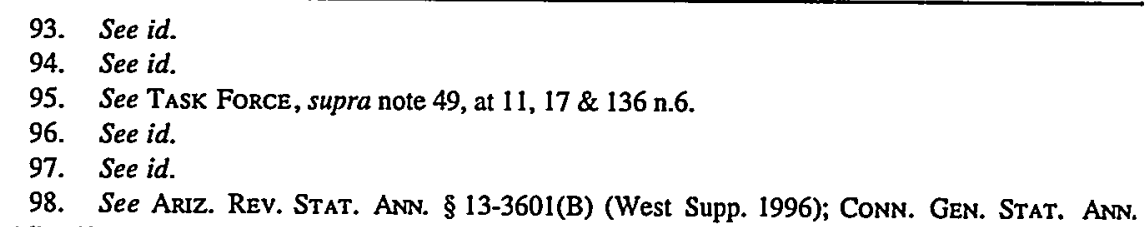
$\S 46 \mathrm{~b}-38 \mathrm{~b}$ (a) (West Supp. 1996); D.C. Code ANN. § 16-1031(a) (1996); Hawall Rev. Stat. ANN. $\S 709-906$ (4) (Michie 1996); lowa Code ANN. $\$ 236.12$ (West Supp. 1996); ME. REv. Stat. ANN. it. 19, § 770(5) (West Supp. 1995); Mo. ANn. Stat. § 455.085(2) (West Supp. 1996); Nev. Rev. Stat. ANN. § 171.137(1) (Michie 1995); NJ. Stat. AnN. \& 2C:25-21 (West Supp. 1996); Or. Rev. STAT. \& 133.055(2)(a) (1995); R.1. GeN. LaWs § 12-29-3(b)(1) (1994); S.D. Codified LaWs § 23A3-21 (Supp. 1996); UtAh Code ANN. § 30-6-8(2) (1993); WASH. Rev. Code ANN. § 10.31.100(2) (West Supp. 1994); Wis. STat. ANN. § 968.075(2) (West Supp. 1994).

99. See Del. Code AnN. tit. 13, § 1510 (1993); ME. Rev. Stat. Ann. tit. 19, § 770(5) (West Supp. 1995); Mass. Gen. Laws Ans. ch. 209A, $\S 6(7)$ (West Supp. 1996); Minn. Stat. AnN. \$ 518B.01(14)(b) (West Supp. 1996); Mo. ANN. STAT. $\$ 455.085(2)$ (West Supp. 1996); Neb. Rev. STAT. § 42-928 (1995); Nev. Rev. StaT. § 33.070 (1991); N.H. Rev. Stat. ANN. \& 173-B:8(1)(a) (1995); N.J. Stat. AnN. §2C:25-21(a)(3) (West Supp. 1996); N.M. Stat. ANN. § 40-13-6(C) (Michie 1996); N.C. Gen. Stat. § 50B-4(b) (1995); OR. Rev. Stat. § 133.310(3) (1993); R.l. GEN. LAwS § 12-29-3(b)(1)(iv) (1996); S.D. Codified LAws ANN. \& 23A-3-21 (Supp. 1996); TENn. Code ANN. § 36-3-61l(a) (1996); Tex. Crim. P. Code ANN. § 14.03(b) (West Supp. 1996); Utah Code ANN. § 30-6-8(1) (1993); Wash. Rev. Code ANN. § 10.31.100(2)(a) (West Supp. 1994); Wis. Stat. ANN. \& 813.122(10) (West Supp. 1994).

100. See Zorza, supra note 77, at 934 . 
Omaha, Nebraska; Milwaukee, Wisconsin; Charlotte, North Carolina; Colorado Springs, Colorado; Metro-Dade (Miami), Florida; and Atlanta, Georgia. ${ }^{101}$

\section{The Replication Experiments}

The results of the replication studies support a variety of conclusions. Most show some evidence of deterrence for all batterers who were arrested. Some of the experiments suggest that arrest may deter employed batterers from repeating violence more effectively than it does unemployed batterers. The Omaha experiment found that the arrest of the abuser led to fewer assaults and injuries to victims during a six-month period following the initial incident. ${ }^{102}$ The Milwaukee experiment also found that repeat violence was lower in the first six months following the arrest of the offender. ${ }^{103}$ In the Colorado Springs experiment, police data demonstrated a slight deterrent effect for abusers who were employed at the time of their arrest. ${ }^{104}$ However, victim interviews from the same experiment showed that arrest was a deterrent for both unemployed and employed abusers. ${ }^{105}$ The Metro-Dade experiment found an increase in recidivism ${ }^{106}$ between one and six months after the incident when the abuser was not arrested. ${ }^{107}$ In the Charlotte experiment, abusers who were arrested were slightly less likely to recidivate after six months than those who received citations. ${ }^{108}$

Although these studies show that arrest is generally the superior method of deterring future violence, some experiments have been cited as suggesting either that arrest does not deter abusers, or, alternatively, that arrest may actually increase recidivism among unemployed abusers. Victim reports, but not police reports, in the Metro-Dade experiment showed a slight increase in violence among unemployed abusers in the six months following their arrest. ${ }^{109}$ The researchers in the Milwaukee

101. See Sherman, supra note 87 , at 2 . Results from the Atlanta, Georgia experiment were never released to the public.

102. See Zorza, supra note 77 , at 942 .

103. See Lawrence W. Sherman et al., The Variable Effects of Arrest on Criminal Careers: The Milwaukee Domestic Violence Experiment, 83 J. CRIM. L. \& CRIMINologY 137, 152-53 (1992).

104. See Richard A. Berk et al., A Bayesian Analysis of the Colorado Springs Spouse Abuse Experiment, 83 J. Crim. L. \& Criminology 170, 181 (1992) (reporting that police data also showed a marginal increase in violence for unemployed offenders who were arrested).

105. See Lawrence W. Sherman et al., Policing Domestic Violence: Experiments and DilemMAS 137 (1992).

106. Recidivism in each study was only measured for domestic violence-related crimes and, as used in this Comment, does not include other criminal activity.

107. See Zorza, supra note 77, at 961 .

108. See J. David Hirschel et al., The Charlotte Spouse Abuse Study, 57 Popular Gov'T 10, 13 (1991).

109. See Zorza, supra note 77, at 961 . 
experiment concluded that arrest did not deter unemployed abusers. ${ }^{110}$ The Omaha experiment reported that unemployed abusers who were arrested were more likely to reoffend than employed batterers. ${ }^{11}$ While official law enforcement data in the Charlotte experiment showed arrest had a negligible deterrent effect on abusers, many victims interviewed reported fewer repeat offenses following arrest. ${ }^{112}$ Finally, the Charlotte experiment found that, although the abuser's employment status was unrelated to his recidivism, his prior criminal history was related to repeat assaults on the victim. ${ }^{113}$

As critics point out, however, these replication studies contained structural flaws that "tended to understate the deterrent value of arrest" on domestic violence. ${ }^{114}$

First, the studies ignored the fact that domestic violence, unchecked, usually escalates in frequency and severity. Thus, repeat offenses are to be expected, and the recidivism rate in an experimental setting should be measured not against zero but against the normal recidivism rate. Accordingly, an intervention strategy could be considered to yield a net improvement based on either an absolute decrease in abuse or a reduced degree of escalation of abuse. ${ }^{115}$

Another important variable ignored by researchers in the replication studies was the effect of prosecutorial and judicial decisions on the arrested abusers' recidivism rate. One experiment that did record this data showed incredibly low rates of prosecution and conviction: ${ }^{116}$

In Milwaukee, for example, only $5 \%$ of the offenders were charged with a crime and only $1 \%$ convicted. In Charlotte, fewer than $1 \%$ of offenders were convicted and incarcerated. Thus, these experiments really studied arrest in the absence of criminal justice follow-up. The experiments did not examine the effectiveness of arrest when there was in fact a coordinated criminal justice [response] involving arrest, prosecution, conviction, and punishment. ${ }^{117}$

Numerous other flaws in the replication studies support the conclusion that they understated the deterrent effects of arrest. In the Milwaukee experiment, for example, police officers' comments to

110. See Sherman, supra note 87 , at 29 tbl.2 (reporting that arrest actually escalased domestic abuse perpetrated by unemployed batterers).

111. See Zorza, supra note 77, at 929-30.

112. See J. David Hirschel \& 1ra W. Hutchinson, 11, Female Spouse Abuse and the Police Response: The Charlotte, North Carolina Experiment, 83 J. CRIM. L. \& CRIMINology 73, 115 (1992).

113. See id. at 103.

114. Zorza, supra note 77, at 930.

115. Id.

116. See id. at 954.

117. Id. at 930-31. 
victims likely discouraged many of them from seeking future police assistance. ${ }^{118}$ Researchers in at least one of the experiments asked victims inappropriate questions that suggested, among other things, that the abuse was somehow the victim's fault, and that tended to minimize the violence and rationalize the batterer's behavior. ${ }^{119}$ Such questions decrease the likelihood that a victim will fully comprehend the danger of her situation. They also permit the victim to continue to blame herself for the violence and allow the batterer to obfuscate his responsibility for his actions. ${ }^{120}$ Several studies also reported an unusually high number of women arrested as abusers, ${ }^{121}$ suggesting that officers may not sufficiently have considered the possibility of women acting in self-defense. Finally, the experiments studied only misdemeanor offenses, ${ }^{122}$ leaving the potential effects of felony arrest and prosecution unexamined. factors.

In addition, the experiments overlooked several other important

[T] he police replication experiments simply did not recognize two important values of arrest in domestic violence situationsarrest offers the victim a window of opportunity to secure safety and it can place her in touch with services that can be of help. Also of great importance is the fact that the mere act of arrest communicates a message that domestic violence is a crime. Given the long history of nonintervention in such cases, indeed of condonation of domestic violence by society, a failure to arrest tells the parties and others that domestic violence is a private matter and is acceptable. ${ }^{123}$

Thus, viewed properly, arrest is an action taken by the state that communicates to society that certain behavior will not be tolerated.

118. See id. at 947 (indicating that law enforcement officers in the Milwaukee experiment were instructed to give a warning message to the couple that "someone will go to jail" if the police are called again, that both parties have a problem and need help, and that both could contact the district attomey's office to file charges).

119. See id. at $976-78$ (discussing the potential negative effects of questions asked by police officers in the Charlotte experiment, which included questions intended to determine the main cause of the fight with possible answers to choose from that iucluded his or her nagging, his or her work around the house, and his or her extramarital affairs).

120. See id. at 977-78.

121. See Sherman, supra note 105 , at 344 (reporting that women represented $9 \%$ of domestic violence offenders in Milwaukce); Berk, supra note 104, at 175 (reporting that $11 \%$ of offenders in the Colorado study were women). However, national studies have shown that women are the abusers in only $6 \%$ of all domestic violence incidents. See Zorza, supra note 77 , at 931 . In addition, $96 \%$ of women arrested for domestic violence offenses are believed to have been acting in self-defense. See id.

122. See Sherman, supra note 87 , at 16 .

123. Zorza, supra note 77, at 931; see also Cheryl Hanna, No Right to Choose: Mandated Victim Participation in Domestic Violence Prosecutions, 109 HaRv. L. REv. 1849, 1889-90 (1996) (stressing the importance of educational and social messages communicated by the criminal justice system). 
"Arresting an offender is a societal statement that his behavior is a crime, that it must stop, that punishment will follow, and that it is sensible to secure treatment to avoid repeating the behavior." 24 Consequently, even if arrest does not provide a stronger deterrent effect than other law enforcement responses, it remains critical to the effective protection of domestic violence victims in our society and to society's conceptualization of domestic violence as a crime against the state.

\section{Understanding Victim Responses to Arrest and Prosecution}

In an attempt to justify the historical noninterventionist approach to domestic violence, defenders of the criminal justice system have been quick to point out that battered women frequently do not want their abusers arrested and often refuse to cooperate in prosecution efforts. This reasoning, however, reflects a fundamental misunderstanding of the dynamics of abuse and underestimates the potential power of prosecutors in domestic violence cases.

It must first be acknowledged that battered women frequently do not want their abusers arrested or prosecuted for the crimes committed against them. ${ }^{125}$ Anyone who has worked with battered women for even a short period of time knows this to be a reality of domestic abuse cases. Actors in the criminal justice system, however, often neglect to consider the fact that victims frequently have valid reasous for resisting involvement in the criminal justice process. These reasons include a legitimate fear of retaliation by the abuser for "pressing charges" against him, fear of economic deprivation caused by payment of bail or days lost from work, and fear of familial and social embarrassment caused by the arrest. ${ }^{126}$ The victim's feelings of self-blame for the assault and her love for her partner further augment her reluctance to turn to the criminal justice system for help. ${ }^{127}$

Furthermore, officers and prosecutors often overlook the many victims who do want their abusers arrested and are willing to assist in the prosecution process if given a minimal amount of encouragement and support. ${ }^{128}$ Studies conducted in California found that with the assistance of victim advocacy programs, only ten percent of domestic abuse victims in Los Angeles and eight percent of victims in Santa Barbara

124. Bouza, supra note 8, at 195.

125. See Zorza, supra note 77 , at 940 (indicating that in the Omaha experiment, $60 \%$ of victims whose abusers were arrested did not want an arrest made).

126. See San Francisco District Attorney's Office, Domestic Violence Felony and Misdemeanor Prosecution Protocol 8-11 (January 1997) (unpublished protocol, on file with the California Law Review).

127. See id.

128. See JONES, supra note 1, at 142-43. 
refused to cooperate with prosecutors. ${ }^{129}$ In San Francisco, seventy percent of victims assisted by the District Attorney's Family Violence Project during its first year of operation said they would not have cooperated with prosecutors without the help they received from advocates. ${ }^{130}$ These findings demonstrate that, despite the incredible hardships battered women face, victims will often be willing to follow through with legal proceedings if given enough support and guidance. Thus, blaming victims for the lack of prosecutions in domestic violence cases cannot be considered a legitimate excuse. This is especially true considering that when prosecutors employ the right methods, they can, in many cases, obtain convictions despite a lack of cooperation from the victim. ${ }^{131}$

\section{E. A Dearth of Viable Civil Remedies for Battered Women}

As state legislatures attempted to cure the criminal justice system's response to battered women by enacting mandatory and pro-arrest schemes, conrts began to strip away battered women's ability to hold local police agencies liable for failing to adequately protect them. In DeShaney v. Winnebago County Department of Social Services, ${ }^{132}$ the United States Supreme Court made it considerably more difficult for battered women to succeed in lawsuits against the police.

DeShaney did not involve a battered woman, but rather a child, Joshua DeShaney, who was repeatedly beaten by his father, Randy DeShaney. In 1980, Joshua's parents divorced, and a court awarded custody of him to his father. Randy soon thereafter moved to Wisconsin, where he remarried. ${ }^{133}$

In January 1982, Randy's second wife notified the Winnebago County Department of Social Services (DSS) that Randy had been physically abusing Joshua. However, after a brief interview with Randy, DSS did not pursue the matter. Twelve months later, Joshua was admitted to the hospital with bruises and abrasions. Although the hospital was granted temporary custody of Joshua after it notified DSS

129. See id.

130. See Naomi R. Cahn \& Lisa G. Lerman, Prosecuting Woman Abuse, in Woman Battering, supra note 8, at $95,103$.

131. See Candace J. Heisler, Evidence and Other Information Sources in Domestic Violence Cases, Prosecutor's BrIEF, Summer 1990, at 24-26 (explaining how prosecutors can effectively try cases despite uncooperative victims); Teri L. Jackson, Lessons Learned From a Domestic Violence Prosecutor, Prosecutor's Brief, Summer 1990, at 23 (giving an example of a case where a conviction was obtained without victim cooperation). Techniques mentioned by Heisler include obtaining and using the victim statement from the scene of the crime, obtaining and using 911 tapes and photos of injuries, subpoenaing paramedic or ambulance reports and other medical records of the victim, and joining other domestic abuse incidents with the pending case.

132. 489 U.S. 189 (1989).

133. See id. at 191. 
of its suspicions of child abuse, only a brief investigation was conducted. Joshua was sent back home to his father just a few days later, after Randy DeShaney entered into a voluntary agreement with DSS in which he promised to attend counseling sessions. ${ }^{134}$

One month later, Joshua was back in the hospital with "suspicious" injuries. In this instance, and others occurring over the next six months, the DSS caseworker recorded the suspected abuse but took no action. In November 1983, Joshua was back in the emergency room. On her next two visits to Joshua's home, the DSS caseworker was told Joshua was too sick to see her. In March 1984, Randy beat four-year-old Joshua so severely that he sustained permanent brain damage. Joshua, who was left profoundly retarded, will spend the rest of his life in an institution. Randy DeShaney was later convicted of child abuse. ${ }^{135}$

Joshua's mother subsequently brought a claim under 42 U.S.C. $\S 1983$ against the Winnebago County DSS and several of its employees who had received complaints about Joshua's abuse..$^{136}$ The suit alleged that DSS had violated Joshua's Fourteenth Amendment right to due process of law by "failing to intervene to protect him against a risk of violence at his father's hands of which they knew or should have known." 137 Chief Justice Rehnquist, writing for the majority, affirmed the lower court's grant of summary judgment in favor of the respondents and rejected Joshua DeShaney's substantive due process claim. ${ }^{138}$ Rehnquist reasoned that

nothing in the language of the Due Process Clause itself requires the State to protect the life, liberty, and property of its citizens against invasion by private actors. The Clause is phrased as a limitation on the State's power to act, not as a guarantee of certain minimal levels of safety and security. It forbids the State itself to deprive individuals of life, liberty, or property without "due process of law," but its language cannot fairly be extended to impose an affirmative obligation on the State to ensure that those interests do not come to harm through other means. ${ }^{139}$

Thus, the Court held that the state is not required to provide a minimum level of safety, even when it is aware of the victim's dangerous situation.

However, the Court also found that in certain limited situations where the state is in a special relationship with an individual, "the Constitution imposes upon the State affirmative duties of care and

134. See id. at 192.

135. See id. at 192-93.

136. See id. at $189,193$.

137. Id. at 193.

138. See id. at 193-95.

139. Id. at 195. 
protection." 140 The Court rejected the argument that Joshua was in such a relationship with the state when he was so savagely beaten. ${ }^{141}$ Rather, the Court narrowly defined the requisite "special relationship" to include only situations in which the state restrains a person's individual freedom, such as incarceration or institutionalization. ${ }^{142}$

Although DeShaney does not directly address claims brought by battered women against police departments, it is evident that it hurts their chances of success. ${ }^{143}$ After DeShaney, a battered woman can effectively bring a substantive due process claim against a police department for failing to protect her only if she fits under one of three narrow exceptions. ${ }^{144}$ These exceptions protect victims who are 1) in a custodial relationship with the state, 2) put in increased danger by a state actor, or 3) injured as a direct result of "inadequate police training." 45

The narrowness of the DeShaney exceptions is illustrated by the Ninth Circuit Court of Appeals' 1990 opinion in Balistreri v. Pacifica Police Department. ${ }^{146}$ The court found that Jena Balistreri failed to demonstrate a special relationship with the Pacifica Police Department despite her acquisition of a valid restraining order against her estranged husband and her repeated requests for protection against his continuous threats, harassment, and violence. ${ }^{147}$ In 1982, Pacifica police officers responding to Balistreri's call for assistance refused to arrest her estranged husband for severely beating her. ${ }^{148}$ Although Balistreri was so seriously injured that she required medical treatment for her nose, mouth, eyes, teeth, and abdomen, the officers did not offer to take her to the hospital or call for an ambulance. ${ }^{149}$ One officer actually told Balistreri that she deserved the beating. ${ }^{.50}$ Throughout 1982, Balistreri complained to the Pacifica Police Department of numerous incidents of vandalism and hundreds of harassing phone calls from her estranged husband, but no further action was taken. In November 1982, Balistreri obtained a restraining order against her former husband, yet the police refused to arrest him even after he crashed his car into her garage. ${ }^{151}$ For the next several months, Balistreri reported additional incidents of

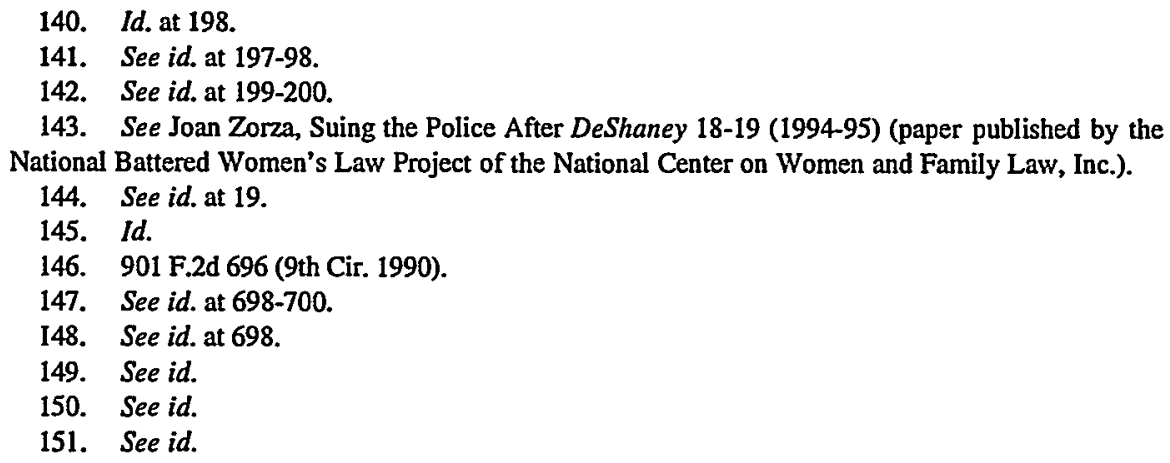


harassment and vandalism, but her complaints were received with ridicule: officers denied that a restraining order was on file, ignored her pleas for protection and adequate investigation, and once even hung up on her when she called to report an incident of vandalism. ${ }^{152}$

Finally, in March 1983, a firebomb was thrown tlirough the window of Balistreri's home. The police, however, took forty-five minutes to respond to Balistreri's 911 call..$^{153}$ Balistreri's home suffered extensive fire damage and Balistreri herself suffered severe emotional distress. After a brief investigation, the police determined that her former husband was not involved, and, when asked to investigate further, told Balistreri "she should either move elsewhere or hire a private investigator." 154 After two more years of constant harassment and vandalism with no law enforcement response, Balistreri filed a complaint against the Pacifica Police Department for violating her constitutional right to due process. ${ }^{155}$

Finding DeShaney controlling precedent, the Ninth Circuit affirmed the district court's dismissal of Balistreri's due process claim. ${ }^{\text {156 }}$ Highlighting DeShaney's limitation of the circumstances giving rise to a "special relationship," the court noted that after DeShaney, the state's affirmative duty to protect arises only when the state takes a person into its custody and restricts his or her freedom to act on his or her own behalf. The duty does not arise simply because the state knows of the individual's plight or expresses an intention to help her. ${ }^{157}$ Accordingly, the court found that "the state's knowledge of [Joshua] DeShaney's plight and its expressions of intent to help him were no greater than its knowledge of [Jena] Balistreri's plight and its expressions of intent to help her."158 Thus, the court dismissed Balistreri's claim because it failed to allege the requisite "special relationship."

Balistreri is not the only case illustrating DeShaney's power to defeat battered women's claims against local police departments. In Pinder v. Johnson, ${ }^{159}$ the Fourth Circuit Court of Appeals, citing DeShaney, reversed a district court decision holding that an officer had an affirmative duty to protect Carol Pinder and her children from her violent ex-boyfriend, even though no custodial relationship existed. ${ }^{161}$ Relying heavily on DeShaney, the court in Pinder found that Officer

152. See id.

153. See id.

154. Id.

155. The complaint asserted several additional claims which I will not discuss as they are beyond the scope of this Comment.

156. See id. at 700 .

157. See id.

158. Id. (citing DeShuney, 489 U.S. at 208-210 (Brennan, J., dissenting)).

159. 54 F.3d 1169 (4th Cir.), cert. denied, 116 S. Ct. 530 (1995).

I60. See id. at 1172. 
Donald Johnson could not be held liable for his failure to safeguard the plaintiff and her children. ${ }^{161}$

On March 10, 1989, Officer Johnson responded to a domestic violence call at the home of Carol Pinder. When he arrived, he found that Pinder's former boyfriend, Don Pittman, had broken into her home, pushed her, punched her, and threatened to murder her and her three children. Pinder informed Officer Johnson that Pittman had just been released from prison after being convicted of attempted arson of Pinder's home approximately ten months earlier. She also asked the officer if it was safe for her to return to work that evening. Officer Johnson assured her that Pittman would not be released from jail that night and indicated that she would have to wait until the next morning to swear out a warrant against Pittman because a county commissioner would not be available that evening. Based on Officer Johnson's assurances, Carol Pinder returned to work. ${ }^{162}$

Later that evening, Johnson brought Pittman before a county commissioner, but only on misdemeanor charges. Consequently, the commissioner released Pittman on his own recognizance. Pittman immediately returned to Pinder's home and set it on fire. Although Pinder had returned to work, her three children were home asleep and died of smoke inhalation. ${ }^{163}$

Pinder later brought suit, claiming Officer Johnson violated her and her children's right to due process by neglecting his affirmative duty to protect them. Although the district court, affirmed by a panel of the Fourth Circuit, found that the plaintiff had established the requisite "special relationship," the decision was reversed after rehearing en banc by the Fourth Circuit. ${ }^{164}$ Upon rehearing, a majority for the sharply divided court found no custodial relationship, as required by DeShaney.

Neither Johnson nor any other state official had restrained Pinder's freedom to act on her own behalf. Pinder was never incarcerated, arrested, or otherwise restricted in any way. Without any such limitation imposed on her liberty, DeShaney indicates Pinder was due no affirmative constitutional duty of protection from the state, and Johnson would not be charged with liability for the criminal acts of a third party ${ }^{165}$

The court bluntly rejected Pinder's assertion that Johnson's explicit promises to her created the requisite "special relationship," holding that "[p]romises do not create a special relationship-custody

161. See id.

162. See id.

163. See id.

164. See id.

165. Id. at 1175. 
does." ${ }^{166}$ Furthermore, the court went on to reject Pinder's contention that her claim was not based on failure to act, but on the affirmative misconduct of Officer Johnson. With similar callousness, the court, revealing its true motivation, argued that if Pinder's argument was accepted,

every representation by the police and every failure to incarcerate would constitute "affirmative actions," giving rise to civil liability.... No amount of semantics can disguise the fact that the real "affirmative act" here was committed by Pittman, not by Officer Johnson. As was true in DeShaney, the state did not "create" the danger, it simply failed to provide adequate protection from it. In both cases, "[t]he most that can be said of the state functionaries... is that they stood by and did nothing when suspicious circumstances dictated a more active role for them."167

As Balistreri and Pinder demonstrate, there is little hope for large liability awards against police departments for violating domestic violence victims' right to substantive due process. Battered women may still, however, pursue other claims against the state for inadequate police protection, including equal protection claims. ${ }^{168}$ While an equal protection claim may seem like a viable choice, several obstacles face plaintiffs in such an action. First, courts will apply the lowest standard of review-rational basis scrutiny-to a claim of discrimination based on status as a victim of domestic violence. ${ }^{169}$ In general, courts are unwilling to consider discrimination against victims of domestic violence as sex discrimination because men are also victims of domestic abuse. ${ }^{170}$ Thus, to invoke a higher level of scrutiny, the plaintiff must prove that a practice or policy's intent or purpose was to discriminate against women. ${ }^{171}$ Evidence that a policy or practice has a disproportionate impact on women is insufficient. ${ }^{172}$ Consequently, unless a victim can present clear evidence of a police department's intent to discriminate against women, such as a policy that evidences a discriminatory intent on its face, her equal protection claim is unlikely to succeed. ${ }^{173}$

166. Id.

167. Id. at 1175-76 (quoting DeShaney, 489 U.S. at 203) (alterations in original).

168. See Zorza, supra note 143, at 19.

169. See id. at 31 .

170. See id.

171. See Personnel Adm'r v. Feeney, 442 U.S. 256, $270-80$ (1979) (holding veterans' preference for civil service jobs did not violate equal protection even though more than $98 \%$ of veterans in Massachusetts were men); cf. Washington v. Davis, 426 U.S. 229, $241-42$ (1976) (discussing the requirement of discriminatory intent or purpose to invoke strict scrutiny in racial discrimination cases).

172. See Feeney, 442 U.S. at 270; see also Davis, 426 U.S. at 242.

173. See, e.g., Feeney, 442 U.S. at $274-80$. 
Battered women may also bring a state tort claim or a procedural due process claim against a police department for inadequate protection. ${ }^{174}$ In addition, if the police are not following their own policies and standards, a battered woman can sue for mandamus or for declaratory or injunctive relief to force the police department to follow its own regulations promulgated to protect her. Domestic violence victims can join together and file a class action suit against a police department for injunctive or declaratory relief, as was successfully done in Scott $v$. Hart and Bruno v. Codd, both inentioned earlier. ${ }^{175}$ Such class action suits, however, require a large number of plaintiffs and a fair amount of documentation showing that a police department is not following its own policies and procedures. ${ }^{176}$ Finally, if such a suit is successful, no monetary relief is available. Courts may only issue an order requiring the police department to follow the law and its own existing policies and procedures. ${ }^{177}$

While these alternative claims remain available to victims, the costs of access to the legal system will still prevent many battered women from pursuing their claims. Most battered women, even those with high household incoines, do not have access to or control over their own finances. ${ }^{178}$ Without money, little can be attained through the U.S. legal system. Furthermore, what had been a promising catalyst for changing law enforcement behavior-the threat of large liability awards-is now limited by DeShaney and its progeny. Consequently, a mandatory arrest scheme, coupled with strong prosecution and judicial enforcement, remains the last meaningful option for ensuring adequate police response to crimes of domestic violence.

\section{II}

\section{The Problem in California}

\section{A. California's Efforts to Combat Domestic Violence}

As the suits against the San Jose, Oakland, and Pacifica Police Departments illustrate, California is not immune to the national epidemic of domestic abuse. The official number of women and children who are abused in California continues to rise each year. In 1993, police and sheriff's departments received 238,895 calls for assistance involving domestic violence incidents, ${ }^{179}$ up more than 38,000

174. See Zorza, supra note 143 , at 19.

175. See supra text accompanying notes $57-72$.

176. See Zorza, supra note 143 , at 38.

177. See id.

178. Economic abuse is a frequent method of control that batterers exercise over their victims. See WALKER, supra note 8, at 127-44.

179. See Crime and Violence Prevention Center, Cal. Att'y Gen.'s Office, Violence Prevention: A Vision of Hope 43 (1995) [hereinafter Violence Prevention]. 
from calls received in $1990 .^{180}$ In 1993, thirty-five percent of all women killed in California were murdered by their spouse or partner. ${ }^{181}$ Women were sixteen times more likely than men to be killed by their spouse or partner. ${ }^{182}$ Although these figures are extremely high, they do not reflect the additional number of women killed by ex-husbands or ex-boyfriends. ${ }^{183}$ This is significant in light of the fact that divorced or separated women represent seventy-five percent of all battered women, ${ }^{184}$ and that battered women are most frequently killed when they attempt to leave their partners or have already left them. ${ }^{185}$ Furthermore, women in California are at the greatest risk of being murdered while in the "safety" of their own homes. More than fifty-one percent of female homicide victims in 1993 were killed at their own residence, while less then twenty-one percent of male victims were killed at home. ${ }^{186}$

This epidemic of domestic violence has not gone unnoticed by California legislators. In 1977, the California legislature responded to the increase in reports of domestic violence by enacting the Domestic Violence Center Act. ${ }^{187}$ The Act provided for the establishment of shelters for battered women throughout the state. The shelters, which are funded with revenues from marriage license fees, provide battered women and their children with safe, although temporary, housing, food and clothing, counseling services, and, in some circumstances, limited legal aid. ${ }^{188}$

180. See California Commission on the Status of Women, Violence: A Profile of California Women 10 (1993) [hereinafter Profile].

181. See Violence Prevention, supra note 179, at 42.

182. See Office of Mgmt., Evaluation and Training, Cal. Dep't of Justice, Homicide in CaLIfornia, 1993, at 11 (1994) [hereinafter Homicide in CALIFoRnia ].

183. Homicides occurring in 1993 were broken down by the sex of the victim and the victim's relationship to the offender and separated into five groups: friend/acquaintance, spouse, parent/child, all other relatives, and stranger. While the "spouse" category includes "'common law' marriage partner[s]," it does not include ex-spouses or former partners. Id. at 65. Ex-spouses and all current and former partners were grouped in the category of "friend/acquaintance," along with employers, employees, and gang members. See id. Consequently, it is impossible to get an accurate picture of how many of the "friend/acquaintance" homicides were actually domestic violence homicides. The "spouse" category, therefore, should be considered a floor for domestic homicide figures, not a ceiling.

184. See Caroline Wolf harlow, U.S. Dep't of Justice, female Victims of Violent CRIME 5 (1991).

185. See David 1sland \& Patrick Letellier, Men Who Beat the Men Who Love Them 257 (1991); see also Mildred Daley Pagelow, Family Violence 43 (1984) (reporting that violence frequently begins only after one party leaves or attempts to leave the relationship); Martha R. Mahoney, Legal Images of Battered Women: Redefining the Issue of Separation, 90 MicH. L. REv. 1, 5-6 (1991) (suggesting renaming domestic violence "separation assaull" to illustrate that the majority of battered women are beaten or killed by their lovers when they leave, or attempt to leave, the violent relationship).

186. See HomictDe in CALIFornia, supra note 182, at 16.

187. See PROFILE, supra note 180 , at 11 .

188. See id. 
In 1985, California expanded financial assistance to battered women's shelters with the Statewide Domestic Violence Assistance program. ${ }^{189}$ The California Office of Criminal Justice Planning reports that sixty battered women's shelters funded by that office in 1990 and 1991 provided crisis intervention to 138,929 victims of domestic violence; counseled 44,508 women and 19,198 children; sheltered 7,981 women and 11,200 children; fed and clothed 21,897 women and children; provided court and social service advocacy to 46,640 domestic violence victims and legal assistance to 23,354 victims; assisted 89,084 new victims of domestic violence; and attracted 383,033 hours of volunteer service. ${ }^{190}$

However, many of these shelters remain desperately underfunded. One estimate indicates that only twenty-five percent of domestic violence victims in California receive the care they need. ${ }^{191}$ While many domestic violence victims are not reached because the crimes committed against them are never reported, many other victims are turned away by shelters that have run out of bed space and by programs that have already exhausted their meager sources of funding. ${ }^{192}$

Even if shelters were adequately funded, however, it is clear, and has been since the beginning of the shelter movement, that providing emergency services to battered women is not enough in itself to stem the rising tide of domestic violence. Measures directed toward prevention and early intervention were lacking. Acknowledging the need for additional efforts, advocates for battered women in the 1970s urged all actors in the criminal justice system to provide a stronger, more effective response to crimes of domestic abuse. ${ }^{193}$ In 1977, the California legislature enacted Penal Code section $273.5^{194}$ to facilitate the arrest of batterers. Section 273.5(a) now provides that

[a]ny person who willfully inflicts upon his or her spouse, or any person who willfully inflicts upon any person with whom he or she is cohabiting, or any person who willfully inflicts upon any

189. See id.

190. See id.

191. See id.

192. See JoNES, supra note 1, at 229-30.

193. See Toni L. Harvey, Batterers Beware: West Virginia Responds to Domestic Violence with the Probable Cause Warrantless Arrest Statute, 97 W. VA. L. Rev. 181, 187-88 (1994); Donna M. Welch, Comment, Mandatory Arrest of Domestic Abusers: Panacea or Perpetuation of the Problem of Abuse?, 43 DePaul L. Rev. 1133, 1143 (1994) (discussing women's advocates' discovery of the epidemic of domestic abuse and their efforts to spur legal and societal change).

194. Cal. Penal Code $\S 273.5$ (West Supp. 1996) (added by Stats. 1977, ch. 912, § 3). 
person who is the mother or father of his or her child, corporal injury resulting in a traumatic condition, is guilty of a felony. ${ }^{195}$

By making spousal abuse a felony, the legislature granted police officers the authority to make an arrest in spouse abuse cases without a warrant and without viewing the actual infliction of injuries. Further facilitating arrests of spousal abusers is the section's broad definition of "traumatic condition," which refers to "a condition of the body, such as a wound or external or internal injury, whether of a minor or serious nature, caused by a physical force."196

To respond more comprehensively to the problems presented by domestic abuse, two years later the legislature enacted the Domestic Violence Prevention Act of 1979. ${ }^{197}$ The Act was intended "to prevent the recurrence of acts of violence and sexual abuse and to provide for a separation of the persons involved in the domestic violence for a period sufficient to enable these persons to seek a resolution of the causes of the violence." 198 The Act established the procedure and guidelines for victims of domestic abuse to obtain temporary restraining orders and more permanent injunctions against their abusers. ${ }^{199}$ It also granted battered women the right to petition the court for temporary custody of their children and to exclude the batterer from the family home. ${ }^{200}$

Ten years later, in an additional legislative effort to protect battered women, the California legislature anended Penal Code section 243, which proscribes misdemeanor battery, to expressly include domestic violence assaults. ${ }^{201}$ The amendinent extended the maximum imprisonment for battery from six months to one year for an assault committed against a former spouse, fiancé or fiancée, or current or former girlfriend or boyfriend. ${ }^{202}$ In so doing, the legislature made a specific

195. Id. $\S 273.5(\mathrm{a})$. This section does not apply to persons who are separated or divorced. See Pcople v. Gutierrez, 217 Cal. Rptr. 616,618 (Ct. App. 1985) (implicitly holding that $\$ 273.5$ does not apply to legally separated spouses).

196. Cal. Penal Code $\$ 273.5$ (c) (West Supp. 1996). See Gutierrez, 217 Cal. Rptr. at 621 (finding that Penal Code $\$ 273.5$ differs from other felony battcry provisions because it provides persons "in intimate relationships with greater protection by requiring less harm to be inflicted before the offense is committed.").

197. CAL. FAm. Code $\$ \S 6200-6389$ (West Supp. 1996) (originally codified by Stats. 1979, ch. $795, \S 10$ at Cal. Civ. Proc. Code $\S \S 540-553)$.

198. Id. $\$ 6220$.

199. See id. \$6250-6257.

200. See id.

201. See CaL. Penal Code $\$ 243$ (e) (West Supp. 1990). In 1990, the statute read:

[w] hen a battery is committed against a noncohabiting former spouse, fiance, fiancée, or a person with whom the defendant currently has, or has previously had, a dating relationship, the battery is punishable by a fine not exceeding two thousand dollars $(\$ 2,000)$, or by imprisonment in a county jail for a period of not more than one year, or by both.

Id. $\S 243(\mathrm{e})(1)$.

202. See id. $\$ 243$ (a) (prescribing the penalty for battery as a fine up to $\$ 2,000$, imprisonment in a county jail not exceeding six months, or both). 
finding that these crimes of domestic violence warrant "special consideration" during sentencing "so as to display society's condemnation for these crimes of violence upon victims with whom a close relationship has been formed."203

Another effort in the struggle against domestic violence came in 1995, when the California legislature amended Penal Code section 13701 to require arrest, absent exigent circumstances, when an officer has probable cause to believe that a valid restraining order has been violated. ${ }^{204}$ This scheme essentially mandates arrest in California for violations of all restraining orders issued by any state. ${ }^{205}$ The amendment also requires law enforcement agencies to adopt policies that encourage arrest in domestic violence cases. ${ }^{206}$

Finally, the legislature enacted two additional-and significantamendments to the Penal Code in 1996, effective January 1, 1997. Penal Code section 243(e) was expanded to include misdemeanor battery against spouses, cohabitants, and persons with whom the offender has a child in common. ${ }^{207}$ Before the amendment, the section had only covered assaults against a former spouse, fiancé, fiancee, or persons in dating relationships. ${ }^{208}$ Penal Code section 836, which delineates officers' authority to make arrests, was amended to allow for a warrantless arrest of a person who "commits an assault or battery upon his or her spouse, upon a person with whom he or she is cohabiting, or upon the parent of his or her child."209 An officer can make such an arrest as long as she has reasonable cause. ${ }^{210}$ The officer

203. Id. § 243(e)(3).

204. See CAL. Penal Code § 13701 (West Supp. 1996) (amended by Stats. 1995, ch. 246, § 4).

205. Congress mandated that states give full faith and credit to restraining orders issued in another state in the Violence Against Women Act of 1994. See 18 U.S.C. $\$ 2265$ (1996).

206. See CAL. Penal Code $\S 13701$ (West Supp. 1996) (amended by Stats. 1995, ch. 246, § 4).

207. See Cal. Penal Code $\S 243$ (e) (West Supp. 1997). The section now reads:

[ $w$ ] hen a battery is committed against a spouse, person with whom the defendant is cohabiting, person who is the parent of the defendant's child, noncohabiting former spouse, fiance, fiancee, or a person with whom the defendant currently has, or previously had, a dating relationship, the battery is punishable by a fine not exceeding two thousand dollars $(\$ 2,000)$, or by imprisonment in a county jail for a period of not more than one year, or by both.

Id. $\$ 243(\mathrm{e})(1)$. The difference between sections $243(\mathrm{e})$ and 273.5 regarding spouses, co-habitants, and co-parents is now solely the degree of harm required: while section 273.5 requires that the victim suffer a traumatic condition, section 243 (e) does not require that the victim suffer any injury, but rather only that an "unlawful use of force" occur. See CAL. Penal Code $\S 242$ (West Supp. 1997) (defining battery).

208. See supra note 201.

209. Cal. Penal Code § 836(d) (West Supp. 1997).

210. Specifically, \& 836(d) provides that

if a person commits an assault or battery upon his or her spouse, upon a person with whom he or she is cohabiting, or upon the parent of his or her child, a peace officer may arrest the person without a warrant where both of the following circumstances apply: (1) The peace offieer has reasonable cause to believe that the person to be arrested has committed the assault or battery, whether or not it has in fact been committed. (2) The peace officer 
no longer needs to view the commission of the offense to make a warrantless arrest under this section. ${ }^{211}$

\section{B. Why These Efforts Are Not Enough}

While these and other laws ${ }^{212}$ enacted to provide greater protection for California's victims of domestic abuse represent tremendous steps forward, they do not go far enough to provide an adequate criminal justice response to the crime of domestic abuse. Penal Code section 836 leaves many victims of domestic abuse without protection, and the changes to Penal Code section 243(e) now make an even more curious and unsatisfying classification of domestic violence victims. Although victims have the ability to make a citizen's arrest when officers refuse to arrest an offender, examination of this option reveals that it is not a viable alternative. Finally, misuse of officer discretion in the existing scheme also works to leave many victims of domestic violence in California unprotected.

\section{The Current Scope of Arrest Power is Too Limited}

The 1996 amendment to Penal Code section 836 only authorizes warrantless arrests for assaults against spouses, cohabitants, and persons with whom the offender has a child in common. ${ }^{213}$ Thus, the law fails to extend similar protection to victims who are divorced or legally separated from their spouses or who no longer live with their abusers. This is significant because the majority of all women who are battered have already left or are attempting to leave their abusive partners. ${ }^{214}$

Section 836 also fails to extend protection to the large number of victims who have, or have had, a dating relationship with the offender, but have never been married to or lived with him. Approximately twenty-eight percent of all persons engaged in dating relationships will experience domestic violence. ${ }^{215}$ This aspect of the statute also neglects the thousands of teens who are beaten by their partners, but who are not

\footnotetext{
makes the arrest as soon as reasonable cause arises to believe that the person to be arrested Id.

has committed the assault or battery, whether or not it has in fact been committed.
}

211. See id.

212. Numerous other statutes in California may be, and frequently are, utilized in the punishment of batterers. See, e.g., Cal. Penal Code $\$ 166$ (West Supp. 1996) (violation of a court order); Cal. Penal Code §§ 244-245 (West Supp. 1996) (assault); CAL. Penal Code $§ 262$ (Wcst Supp. 1996) (marital rape); Cal. Penal Code $§ 273.6$ (West Supp. 1996) (violation of a restraining order). Still others provide additional services or assistance aimed at aiding battered women and their children. See, e.g., CAL. FAM. CODE $\$ \$ 6300-6389$ (West Supp. 1996) (providing for the enforcement of domestic violence restraining orders); CAL. WELF. \& INST. CODE \$§ 18290-18307 (West Supp. 1996) (indicating legislature's intent to support domestic violence centers and treatment progmms).

213. See Cal. Penal Code $\$ 836$ (d) (West Supp. 1997).

214. See Harlow, supra note 184.

215. See Suarez, supra note 4 , at 426. 
married and still live at home with their parents. Approximately onethird of all females will experience some form of abuse in the context of a dating relationship by age twenty. ${ }^{216}$

It is not entirely clear why the legislature limited warrantless arrests to only certain victims of domestic violence. In presenting the bill containing this amendment to section 836, Assembly Bill 2116 (AB 2116), Representative Alby, who sponsored the bill, made the following argument to the Senate Committee on Criminal Procedure:

Current standards governing law enforcement intervention in misdemeanor domestic violence cases are not practical, requiring that the assault occur in the officer's presence.

Since the vast majority of domestic violence assaults are over before the officer arrives, there is little assistance they [sic] can offer in this situation. Furthermore, since domestic violence is usually a cycle rather than a singular event, early intervention will most effectively break the chain of violence.

$\mathrm{AB} 2116$ will give law enforcement the ability to make arrests for domestic violence assaults if they have probable cause, providing greater protection to victims, before the cycle of violence swings wildly out of control, resulting in serious injury or death. ${ }^{217}$

Obviously, this language, which does not differentiate among victims of domestic violence by their relationship to the abuser, fails to elucidate why the language in the amendment protects only a subset of victims.

Although the effort may have been well-intended, the California legislature, in making this change, appears literally to have forgotten domestic violence victims who are ex-spouses, ex-cohabitants, fiancés, fiancées, boyfriends or girlfriends of the offender. These victims of domestic abuse are non-existent in the legislative history of the bill. ${ }^{218}$ The omission is particularly distressing considering the higher risk of severe assault and death many of these victims face. ${ }^{219}$ It is also ironic because these victims were previously the only victims covered under section 243(e), which proscribes misdemeanor battery. Instead of allowing for warrantless arrest for assaults against all victims specified in section 243(e), the legislature only extended the protection to the newly added victims from section 273.5. Thus, officers still need to obtain a warrant for assaults against ex-spouses, ex-cohabitants, fiancés, fiancées, and boyfriends and girlfriends, but not for assaults against spouses,

216. See id. at 426,430 .

217. See California Senate Comm. on Crim. Proc., Analysis of AB 2116, June 11, 1996, available in LEXIS, Legis Library, Cacomm File.

218. See id.

219. See 1sland \& Letellier, supra note 185, at 257; Pagelow, supra note 185, at 43; Bachman \& Saltzman, supra note 8 , at 4 . 
cohabitants, and co-parents, despite the fact that the arrests are occurring under the same Penal Code section. Clearly, these separate standards draw a false distinction among victims of domestic abuse and leave many victims needlessly unprotected.

\section{Citizen's Arrest Is Not a Viable Alternative}

One alternative for these unprotected battered women is for the women themselves to make a citizen's arrest of their abusers for the crimes committed against them. Section 837 of the California Penal Code permits a private citizen to arrest another person "[f]or a public offense committed or attempted in his presence."220 Furthermore, officers must make a good faith effort to inform every victim of domestic violence they encounter of her right to make a citizen's arrest. ${ }^{221}$ To make a citizen's arrest, the victim must sign a sworn complaint alleging the crimes committed against her and identify the defendant as the person who committed those crimes. Once the victim signs the complaint, she may request an officer's assistance in taking the defendant into custody. ${ }^{222}$

Making a citizen's arrest, however, could entail serious consequences. First, the victim-not the police department as is usually the case-may be subject to civil liability for the arrest if a court later determines that it was made unlawfully. ${ }^{223}$ Since many batterers force their partners to quit their jobs or completely control the finances of both parties, ${ }^{24}$ most battered women are unable even to retain an attorney to respond to-let alone adequately defend against-such liability claims.

Second, asking a victim in front of her abuser whether she wants to make a citizen's arrest places her in a very difficult situation. Even if she wants her abuser arrested, she may be too afraid to say so in front of him.

Third, requiring the victim to make her own citizen's arrest of her abuser makes it easier for both the abuser and the victim to blame the victim for the subsequent incarceration. If any retaliation for the arrest is imminent, it is very clear to the batterer that in this situation the woman, not the officer who refused to make an arrest, is to blame. Since most victims already feel responsible for their abuser's behavior, forcing them to make a citizen's arrest only compounds their gnilt.225 A

220. Cal. Penal Code $\$ 837$ (West Supp. 1996).

221. See Cal. Penal Code § 836(b) (West Supp. 1996).

222. See Cal. Penal Code $\$ 839$ (West Supp. 1996).

223. See Cal. Penal Code $\S 847$ (West Supp. 1996).

224. See WALKER, supra note 8, at 127-44; see also LeNORE E WALKER, TERRIFYING Love: Why BatTered WOMEN Kill aNd How Society Responds 323 (1989) (discussing the financial difficulty battered women criminal defendants have in securing comprehensive legal representation).

225. See WALKER, supra note 8 , at 15. 
citizen's arrest also fails to communicate to battered women that society does not condone and will not tolerate the crimes their loved ones commit against them. Rather, it reinforces their belief that the police will not intervene in this "private matter" and that they are responsible for any consequences their abusers face.

Fourth, forcing victims to make citizens' arrests of their abusers incorrectly conceptualizes domestic violence as a private matter, where private parties determine the criminality of others' actions. Domestic violence, however, is not just a crime against an individual, but is a crime against the state that affects the entire society. Refusing to recognize it as such enhances the batterer's isolation of and control over his victim, thereby fostering the unchecked continuation and escalation of the cycle of violence.

\section{Too Much Discretion for Police Officers Leaves Victims Unprotected}

Traditional biases against taking official action for crimes committed in the "domestic sphere" of life further contribute to the lack of law enforcement action in domestic violence cases. ${ }^{226}$ Domestic violence calls are still considered, by both law enforcement officers and prosecutors, to be low priority and almost a rite of passage for the rookies to endure until they are promoted to "bigger and better" things, such as felony robbery and homicide cases.

Some police chiefs have gone as far as bringing disciplinary actions against their own officers to implement departmental policies to arrest perpetrators of domestic abuse. ${ }^{227}$ Not all police chiefs, however, are willing to take such "extreme" measures. Thus, line officers, who wield enormous power in determining how laws are or are not enforced on the streets, are often able to handle domestic violence calls according to their personal prejudices and biases. ${ }^{228}$

They will continue, in other words, to abet the batterer and deprive his victim of her safety, her freedom, and her constitutional rights.

\footnotetext{
Blaming women for causing men to batter them has resulted in their shame, embarrassment, denial, and further loss of self-esteem. The batterer feels justified in his violent behavior because society says it is really the woman's fault, not his. It perpetuates his notion that he should beat her because she did something to make him angry. What gets lost in this victim precipitation ideology is the fact that such violence is not acceptable behavior. Id.

226. See JoNEs, supra note 1 , at 141-42.

227. See id. at 142.

228. See id.; see also Bouza, supra note 8, at 192-96. For a general discussion of problems raised by officer discretion, see Susan S.M. EdWARDS, Policing 'Domestic' Violence: Women, THE LAW AND THE STATE 82-110 (I989).
} 
[D]espite dramatic changes in state and municipal law enforcement policies, many cops still conduct business as usual, enforcing not the law but the do-nothing policy they know best. ${ }^{229}$

Thus, strong policies and procedures promulgated by police departments are unlikely to produce significant change. The laws of California must clearly dictate to police departments throughout the state exactly what their duties are in regard to crimes of domestic violence. Only under such clear requirements will California's victims of domestic abuse be adequately protected.

III

A Statutory Remedy: One Piece of the Solution

\section{A. Creating Warrantless Arrest for All Misdemeanor Crimes of Domestic Violence}

Rather than placing the burden on battered women to make a citizen's arrest or requiring that officers actually view the commission of a domestic violence crime before making an arrest, California should modify existing law to eradicate the distinction among types of victims of domestic abuse based on their relationship to the offender. In so doing, California would provide equal treatment for all victims of domestic violence.

As illustrated in Part II, California Penal Code section 836 allows officers to make a warrantless arrest of a person who assaults his or her spouse, cohabitant, or person with whom he or she has a child in common. However, the exclusion of ex-spouses, former cohabitants, and current or former dating partners from section 836 exempts many domestic abuse victims from the statute's added protections.

Consequently, legislative change is necessary to provide a consistent, authoritative response to domestic violence in California. Penal Code section 836 should be amended to include assaults against exspouses, ex-cohabitants, fiancés and fiancées, and current or former boyfriends and girlfriends. As revised, section 836 should read:

if a person commits an assault or battery upon his or her current or former spouse, upon a person with whom he or she is cohabiting or has cohabitated, upon the parent of his or her child, upon a current or former fiancé or fiancée, or upon a person with whom the person has or has had a dating relationship, a peace officer may arrest the person without a warrant where both of the following circumstances apply: (1) The peace officer has reasonable cause to believe that the person to be arrested has committed the assault or battery, whether or not it has in fact been committed. (2) The peace officer makes the arrest as soon

229. JONES, supra note 1, at 142. 
as reasonable cause arises to believe that the person to be arrested has committed the assault or battery, whether or not it has in fact been committed. [Additions emphasized.]

These changes create consistency and provide equal treatment to all victims of domestic abuse. They also eliminate the officer's need to ascertain at the scene the precise nature of the relationship between the parties, which can often be an arduous task. ${ }^{230}$ The officer would simply need to establish that the parties are, or have been, engaged in an intimate relationship that falls into one of the broad categories specified above. Moreover, these changes also acknowledge the extreme danger all victims of domestic violence face when they are left to endure abuse without law enforcement assistance. ${ }^{231}$ They provide a simple and effective way for the legislature to increase protection to victims of domestic abuse currently neglected by California law.

Authorizing warrantless arrest for domestic violence assaults, however, does not guarantee that officers will actually make arrests in these cases. Additional legislative change is needed to adequately protect California's victims of domestic abuse.

\section{B. Mandating Arrest When Officers Have Probable Cause That Domestic Violence Has Occurred}

Allowing for warrantless arrests of all batterers who assault their partners is only the first of many steps needed to change the criminal justice system's response to domestic violence in California. To provide a trnly adequate response to incidents of domestic abuse, California must enact a statute mandating arrest when officers have probable cause to believe a domestic assault has been committed. ${ }^{232}$

In adopting a mandatory arrest scheme, California would join fifteen states and the District of Columbia, where arrest is currently mandated in domestic violence incidents. ${ }^{233}$ The precise definition of a "domestic violence incident," however, differs from state to state. ${ }^{234}$

230. The author has read dozens of police reports where the parties at the scene of a domestic violence incident represent themselves to officers as husband and wife when they are not actually married. Parties often also misrepresent, or disagree upon, the on-going nature of their relationship.

231. See Harvey, supra note 193, at 203.

232. The recommended approach is first to expand warrantless arrest to cover assaults against all domestic violence victims, and then to enact mandatory arrest, with a phase-in time for education and training.

233. See Joan Zorza \& Laurie Woods, Mandatory Arrest: Problems and Possibilities 11 (1994) (paper published by the National Battered Women's Law Project of the National Center on Women and Family Law, lnc.) (reporting that fourteen states have a mandatory arrest scheme). Colorado adopted mandatory arrest in 1994. See Colo. REv. STAT. ANN. \$ 18-6-803.6 (West Supp. 1996).

In adopting mandatory arrest, California would also become eligible for federal grants, which are now available to states and local governments implementing mandatory arrest schemes. See 42 U.S.C. \$ 3796hh (1996).

234. See Zorza \& Woods, supra note 233, at 11. 
For example, some states mandate arrest only for acts that result in visible physical injuries, ${ }^{235}$ while others, at a minimum, require the commission of a physical act that causes another person reasonably to fear the imminent infliction of pain, injury, or illness. ${ }^{236}$

In California, the simplest way to enact mandatory arrest within the state's existing legislative framework is to amend Penal Code section 836 , in addition to the amendment previously mentioned, to require arrest in certain domestic violence incidents. A new section, Penal Code section $836(\mathrm{e})$, could be added to the statute. This section could read:

(e) When a peace officer has reasonable cause to believe a person has committed an assault or battery upon his or her current or former spouse, current or former cohabitant, current or former fiancé or fiancée, a person with whom he or she has or has had a dating relationship, or the parent of his or her child, the peace officer shall arrest the person if the person is the primary physical aggressor ${ }^{237}$ in the incident.

(1) The primary physical aggressor is the person determined to be the most significant, rather than the first, aggressor. In identifying the primary physical aggressor, an officer shall consider:

(A) the intent of the law to protect victims of domestic violence from continuing abuse;

(B) the threats creating fear of physical injury;

(C) the history of domestic violence between the parties; and

(D) whether either person involved acted in self-defense. ${ }^{238}$

While this statutory language may not be ideal ${ }^{239}$ it is the most appropriate way to legislate mandatory arrest in California without major revision of the Penal Code. It is consistent with the phraseology used in other Penal Code sections relating to domestic violence. Thus, this approach should reduce the possibility for confusion and misinterpretation. Moreover, in limiting mandatory arrest to domestic assaults and batteries, the amendment takes a middle approach to the degree of harm

235. See, e.g., ARIZ. Rev. Stat. AN. \& 13-3601(B) (West Supp. 1996).

236. See, e.g., WIs. Stat. ANN. § 968.075 (West Supp. 1994).

237. In discussing arrests for restraining order violations, Penal Code $\$ 836(\mathrm{c})$ dictates that officers shall consider the "primary aggressor" in the incident. See CAL. PENal CODE $\$ 836$ (c)(3) (West Supp. 1997). However, the author prefers the term "primary physical aggressor," as used in several other state codes. See, e.g., Mo. ANN. STat. $\$ 455.085$ (West 1996); NEv. Rev. Stat. ANN. $\S 171.137$ (2) (Michie 1995); WASH. Rev. CODE ANN. $\$ 10.31 .100(2)$ (b) (West Supp. 1994); Wis. STAT. ANN. \$ 968.075(3)(a) (West Supp. 1994). This term better reflects that the person to be arrested is the person who poses the greatest threat to the other party's physical safety. Consequently, Penal Code $\S 836(\mathrm{c})$ should be amended to read "primary physical aggressor" to provide for a consistent approach between the two sections.

238. These factors are identical to those found in Penal Code $\$ 836(\mathrm{c})(3)$ for determining the primary aggressor in a domestic violence incident involving a restraining order violation.

239. If able to start from scratch, the author would prefer not to list groups of included persons. Rather, the author would prefer to mandate arrest for all "domestic-violence related assaults and batteries" with the scope of the term "domestic violence" clearly defined earlier in the statute. 
required in comparison to other states. ${ }^{240}$ In so doing, it strikes a balance between the interests of the state and the rights of the defendant.

This amendment, however, is not the only legislative change needed to enact an effective mandatory arrest scheme. Included in the bill proposing this amendment should be legislation requiring extensive training for police officers, prosecutors, and judges on the following subjects: the nature of domestic violence, the need to identify and prosecute only the primary physical aggressor, how to provide a culturally sensitive response to all domestic abuse victims, the dynamics of abuse in same-sex relationships, and appropriate responses to undocumented victims of abuse. This bill should also include increased funding for battered women's shelters and advocate services, particularly for victims who are also members of racial or cultural minorities, to provide a comprehensive community response to domestic violence. ${ }^{241}$

As part of legislation creating the foundation for an effective coordinated community response, California's mandatory arrest statute will fill a void in current state law. Although critics may argue that California's existing laws-such as laws that require police departments to adopt a "pro-arrest policy" and mandate arrest for restraining order violations-provide victims with adequate protection, upon closer examination, California's existing laws do little to change traditional police practices in domestic violence situations and place a burden upon some victims of domestic abuse that no other victims of crime are forced to bear.

\section{Why Pro-Arrest Policies and Mandatory Arrest for Restraining Order Violations Do Not Alleviate the Need for Mandatory Arrest}

In 1995, the California legislature amended Penal Code section 13701, which addresses law enforcement response to domestic violence. The amendment requires every law enforcement agency in the state to develop, adopt and implement policies that 1) encourage arrest in domestic violence cases; 2) require arrest, absent exigent circumstances, if a restraining order has been violated; and 3) discourage dual arrest in domestic violence cases by instructing officers to make reasonable efforts to identify the primary aggressor. ${ }^{242}$ These policies, required to take effect by July 1,1996, were to be developed with the input of local domestic violence agencies. ${ }^{243}$

240. See Marion Wanless, Mandatory Arrest: A Step Toward Eradicating Domestic Violence, But Is It Enough?, 1996 U. IL. L. Rev. 533, 557-61.

241. See infra Parts $1 \mathrm{~V}, \mathrm{~V}$.

242. See CAL. Penal CODE $\$ 13701$ (b) (West Supp. 1996); see also supra note 237 (arguing for a change in the terminology to "primary physical aggressor").

243. See id. 
Although this legislation garnered strong support from domestic violence advocates in California, support for mandatory arrest among advocates is fairly weak. ${ }^{244}$ Many advocates favor the type of pro-arrest policy found in the amendment to section 13701, because they believe that officers should retain a certain amount of discretion, primarily to prevent a "backlash" against women. ${ }^{245}$ Most states have adopted a pro-arrest stance to domestic violence cases, and twenty-one states currently mandate arrest only for violations of restraining orders. ${ }^{246}$ Advocates have been more willing to support mandatory arrest for these offenses because the abuser is aware that if he violates the protection order, he will face criminal charges. Furthermore, advocates believe more victims would desire-and even expect-police protection in these

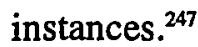

Although pro-arrest policies and mandatory arrest for restraining order violations are extremely significant steps in the improvement of law enforcement response to domestic violence, the experiences of several communities show that more is needed to curb domestic abuse in our culture. While most states currently have a "pro-arrest" policy statute on the books, such policies merely "encourage" arrests and are largely without teeth. They rarely require any specific change in officer behavior. Furthermore, even in communities where pro-arrest policies have been taken seriously and enforced, arrests have increased less dramatically than when a mandatory arrest policy was enacted. ${ }^{248}$

In addition, those who advocate pro-arrest policies over mandatory arrest policies base their position on several flawed assumptions. For instance, pro-arrest advocates assert that a pro-arrest policy is better because a mandatory arrest policy deprives police officers of all discretion..$^{249}$ However, this is simply not true. Mandatory arrest laws instrnct officers to make arrests when they have determined there is probable cause to believe certain crimes of domestic violence have been committed. Hence, officers do not mechanically make arrests in response to every domestic abuse call. To the contrary, officers, using

244. Interview with Nancy K.D. Lemon, lecturer on domestic violence at Boalt Hall and member of the Califomia Alliance Against Domestic Violence (Nov. 11, 1996).

245. See Zorza \& Woods, supra note 233 , at 10 . Advocates fear that forcing officers to arrest in domestic violence cases will anger officers, cause them to blame women for the increase in their workload, and lead officers to retaliate by arresting women.

246. See id. at 11. California became the twenty-first state to mandate arrest for restraining order violations when it passed Penal Code section 13701, effective July 1, 1996. See CAL. PeNAL CoDE $§ 13701$ (b) (West Supp. 1996).

247. See Zorga \& Woods, supra note 233 , at 11.

248. See id. at 12 .

249. See, e.g., Welch, supra note 193, at 1150, 1158; Pamela Blass Bracher, Mandatory Arrest for Domestic Violence: The City of Cincinnati's Simple Solution to a Complex Problem, 65 U. CIN. L REv. 155, 170 (1996). 
their skills and training, must make arrests when they have probable cause to believe that the law has been violated. The probable cause determination also requires officers to use their trained judgment in sorting out incidents in which the facts are in dispute. Consequently, officers in mandatory arrest jurisdictions still retain some discretion and must continue to use their decision-making skills and training before making an arrest.

Another false assumption held by some pro-arrest advocates who criticize mandatory arrest is that the only function of arrest is to decrease domestic abuse recidivism. This assumption leads some advocates to conclude that a pro-arrest policy is the best choice because officers may choose to arrest only those batterers whom society believes will be deterred by arrest and incarceration. ${ }^{250}$ This view neglects the numerous other functions served by arrest in domestic violence cases, such as allowing victims the opportunity to achieve safety, communicating that domestic abuse is a crime against the state and not an event between two private persons, and punishing batterers for violating the law.

[J]ust because the arrests do not provide a perfect and infallible deterrent is no reason to decide that they do not work.

"There's deterrent, but also punishment....We don't have people calling for the repeal of burglary laws because they don't have a deterrent effect. Why not arrest someone who has committed a crime? A crime is a crime is a crime. It should be treated the same in a home as it is on the street." 251

Furthermore, the effect of this view is that victims of unemployed abusers, career criminals, and others whom society doubts will be deterred by arrest ${ }^{252}$ are left to fend for themselves, terrorized by their abusers and abandoned by a society that refuses to protect them. In light of the economics of racism, ${ }^{253}$ this approach has a considerable discriminatory impact on poor women and women of color. Consequently, a different approach is needed if all victims of domestic abuse are to be treated equally and provided with adequate police protection. A mandatory arrest scheme provides just such an approach.

250. See, e.g., Welch, supra note 193, at 1160 .

251. Harvey, supra note 193, at 211 (quoting Jennifer Toth, New Study of Domestic Violence Finds Mandatory Arrests Backfire, L.A. Times, Dec. 18, 1991, at A5).

252. See Welch, supra note 193, at 1155 (citing the Milwaukee study conducted by Lawrence Sherman suggesting that unemployed abusers are not deterred by arrest); see also SHERMAN, supra note 105 , at 148 (concluding that arrest provides a much stronger deterrent effect for batterers whose victims are white and Hispanic than it does for abusers whose victims are African-American).

253. See Roy L. Brooks, The Ecology of Inequality: The Rise of the African-American Underclass, 8 HARv. BLACKLETTER J. 1, 2 (1991) (discussing the connections between racism against African-Americans and poverty). 
IV

Responding to the Critics: Addressing Concerns ABOUT MANDATORY ARREST

Mandatory arrest is not a new concept. The trend of enacting mandatory arrest laws came to a somewhat abrupt halt in the late 1980s by the purported results of the replication studies and by victim advocates who feared mandatory arrest laws had several unintended and undesirable effects. These advocates' concerns included fears of increased violence following arrest, inappropriate arrests of victims of domestic abuse, a general violation of victim autonomy, discriminatory impact on people of color, as well as gays and lesbians, and adverse affects on undocumented battered women in California.

As demonstrated in Part $I$, the replication studies are inconclusive and are not a reliable source of information on which to base public policy. Consequently, advocates' concerns about possible consequences of a mandatory arrest law remain the primary obstacle blocking the enactment of a mandatory arrest law in California. While these concerns are valid and deserve full legislative consideration, upon examination they do not provide a sufficient basis to deny domestic abuse victims mandatory enforcement of the law for the crimes committed against them.

\section{A. Arrest Interrupts the Expected Escalation of the Cycle of Violence}

Citing several of the replication studies discussed in Part I, a number of commentators argue that arrest of abusers is at best a waste of resources, because it has no deterrent effect, and at worst harmful to victims of domestic abuse, because arrest increases repeat violence. ${ }^{254}$ This argument errs by assuming that batterers commit repeat offenses solely in retaliation for the original police arrest. As explained in Part I, domestic violence within individual relationships escalates over time in frequency, intensity, and duration. ${ }^{255}$ Both the Minneapolis experiment and the replication studies, which are most frequently cited for the proposition that arrest mcreases domestic violence, failed to take this factor into consideration. Consequently, rather than viewing arrest as failing to deter batterers, subsequent offenses should be expected as a matter of course. ${ }^{256}$ Thus, the conclusion that arrest angers abusers and

254. See generally SHERMAN, supra note 105; Frank J. Remington, LaFave on Arrest and the Three Decades That Have Followed, 1993 U. lLL. L. Rev. 315 (1993); Miriam H. Ruttenberg, A Feminist Critique of Mandatory Arrest: An Analysis of Race and Gender in Domestic Violence Policy, 2 AM. U. J. GENDER \& L. 171 (1994); Welch, supra note 193.

255. See WALKER, supra note 8, at 57.

256. See Zorza, supra note 77, at 930. 
causes many of them to reoffend against their victims is incorrect and unfounded.

The best available evidence on arrest's deterrence of the escalation of domestic violence is the vast decrease in domestic violence homicides under mandatory arrest schemes. After enacting mandatory arrest, Quincy, Massachusetts had only one domestic abuse homicide in ten years, while neighboring boroughs reported nearly fifteen or more each year. ${ }^{257}$ San Diego reported a seventy percent decrease in domestic violence homicides in the five years following its adoption of mandatory arrest. $^{258}$ In addition, domestic violence incidents involving serious bodily injury in Connecticut dropped from 600 in 1987 to 500 in 1992 following that state's enactment of mandatory arrest in $1986 .^{259}$ These examples support the conclusion that while arrest will not stop battering, it will decrease the expected escalation of the cycle of violence.

\section{B. Safeguards Can Be Taken to Protect Against Dual Arrests}

Another fear of many advocates is that a mandatory arrest scheme will result in officers arresting both parties involved in a domestic violence incident, called a dual arrest. Advocates fear that many women will be arrested, even though they are actually victims of domestic abuse who injure their abusers while acting in self-defense. Because data indicate that approximately ninety-five percent of domestic assaults in the United States are committed by men, experts expect no more than five percent of arrested offenders will be women. ${ }^{260}$ Experiences in several states, however, reflected much higher percentages of women arrested following the introduction of mandatory arrest laws, therefore providing support for advocates' concerns. ${ }^{261}$

The state of Washington's experience provides a good lesson for states concerned about a backlash against victims of domestic abuse. Washington, which was among the first states to enact a mandatory arrest law, passed its Domestic Violence Prevention Act in $1984 .{ }^{262}$ The act

257. See Stephanie B. Goldberg, Nobody's Victim, A.B.A. J., July 1996, at 48.

258. See Lisa Stansky, Prosecuting Without the Witness, A.B.A. J., July 1996, at 50.

259. See Wanless, supra note 240 , at 559.

260. See The DATA, supra note 8, at 21; see also Russell P. Dobash et al., The Myth of Sexual Symmetry in Marital Violence, 39 Soc. ProBs. 71, 75 (1992).

261. See Zorza \& Woods, supra note 233, at 16-20 (citing higher-than-expected rates of dual arrests following the implementation of mandatory arrest in Connecticut (14\%), Duluth, Minnesota (women were $9.3 \%$ of those arrested following pro-arrest, $6.9 \%$ following mandatory arrest), Wisconsin (5.5\% dual arrests in $1989,6.1 \%$ in 1990 , and $7.7 \%$ in 1991), Iowa (15\% of those arrested were women), and Kansas City, Missouri (women's arrest rate of 20\%)). Several of these states and cities, along with Oregon, have added the primary physical aggressor standard to their statutes to help reduce the number of dual arrests. See id. at 19.

262. See Susan Wilder Crane, Washington's Domestic Violence Prevention Act: Mandatory Arrest Two Years Later, Women's Advoc., May 1987, at 1. 
required officers to make an arrest if they had probable cause to believe the suspect had assaulted a family or household member. ${ }^{263}$ Soon after the law's implementation, reports surfaced throughout the state that many battered women were being arrested along with their abusers. ${ }^{264}$ These dual arrests were attributed to several problems including inadequate police training, officer fear of liability for failing to protect men who complained of assault, and officer resentment toward the limitation of their discretion in domestic violence cases. ${ }^{265}$ As a result, many officers interpreted the statute to mandate the arrest of all persons involved in the incident, without giving sufficient consideration to other factors, such as self-defense.

The Washington legislature quickly moved to eradicate this misinterpretation by adding a "primary physical aggressor" standard to the statute. ${ }^{266}$ This standard called for officers to conduct a brief investigation at the scene to determine who was the main aggressor and to arrest only that person. Police were explicitly told in the revisions to the statute that they were not required to arrest both parties, but should instead arrest only the primary physical aggressor. ${ }^{267}$ In determining who was the primary physical aggressor, officers were to consider comparative injuries, history of domestic abuse, actions taken in self-defense, and the intent of the statute to protect victims of domestic abuse. ${ }^{268}$ Interestingly, the number of dual arrests decreased dramatically even before the amendment went into effect due to the additional police training and the officers' growing comfort with the new law. ${ }^{269}$ After the implementation of the "primary physical aggressor" amendment, the number of dual arrests continued to drop. ${ }^{270}$

A strong primary physical aggressor standard is crucial to an effective mandatory arrest law because the repercussions of dual arrests are severe. Women are far less likely to report further battering when they fear they will be arrested. Many battered women who are arrested are, in effect, being punished for protecting themselves in selfdefense. ${ }^{271}$ The arrest may prevent them from defending themselves in

\footnotetext{
263. See id.

264. See id.

265. See id.

266. See id.

267. See id.

268. See id:

269. See id.

270. See id.

271. See Zorza, supra note 77, at 980-81 (citing reports from batterer's treatment programs that the vast majority of female 'offenders' referred to their programs by the court were actually victims, often women who had acted in self-defense). EMERGE, the oldest batterer's treatment program in the country, reported that "virtually every woman referred to its program was actually a victim who was wrongfully arrested." Id. at 980 (footnote omitted); see also John Johnson, A New Side to
} 
the future, thus jeopardizing their own safety. Furthermore, arresting the victim only enhances her own sense of guilt and responsibility for the abuse, while contributing to the batterer's denial of accountability and blame of the victim. The end result is that women who have been assaulted may be revictimized by the very system to which they turned for help.

Battered women with children may further suffer if the state social services takes temporary custody of the children after a dual arrest. ${ }^{272}$ These mothers, caught in the web of the social service system, are vulnerable to further manipulation from their abusers, and some may even lose permanent custody of their children. ${ }^{273}$ Even those mothers who are spared by social services still risk losing their children as a result of a wrongful arrest. Forty states currently have statutes that make domestic abuse at least one of the factors that judges must consider when determining who should have custody of the children. ${ }^{274}$ Although the goal of these statutes was to assist victims of abuse in obtaining legal custody of their children, the inappropriate arrest may cause the mother to lose this advantage. As a result, she may lose custody of her children altogether, leaving the children in the hands of an abusive father ${ }^{275}$ This outcome directly contravenes the policy concerns driving mandatory arrest laws and statutes which favor the non-violent parent in custody disputes.

California must learn from the mistakes and experiences of Washington and other states to prevent this revictimization of women and children through dual arrests. A strong and clear primary physical aggressor standard must be the centerpiece of California's mandatory arrest legislation. ${ }^{276}$ In addition, all actors in the criminal justice system, especially police officers, must receive significant training on the dynamics of abuse, the primary aggressor standard, and the concepts of self-defense as they appear in the domestic violence context. It is

Domestic Violence, L.A. Times, Apr. 27, 1996, at AI (reporting that most women arrested for domestic violence offenses in Los Angeles County are not prosecuted).

272. See Zorza \& Woods, supra note 233, at 23-24. A survey in Wisconsin indicated that about $5.7 \%$ of the children surveyed were placed in the temporary custody of a social service agency following the arrest of their mother, while an additional $2.9 \%$ remained in the agency's custody until further action could be taken. See id.

273. See id. at 24.

274. See id.

275. See id.

276. See supra Part III.B (discussing proposed statute). A study on dual arrests in Wisconsin found that the way prosecutors and law enforcement personnel interpreted that state's primary physical aggressor standard was a key factor in accounting for dual arrest rates. See OFFICE OF Crime Victim Services, Wis. Dep't of Justice, Domestic Abuse Incident Report for 1992 AND 1993, at I1 (1994) [hereinafter 1992-93 REPORT]. The counties that interpreted the standard to mean that only the primary physical aggressor should be arrested had the lowest dual arrest rates. See id. at 12. 
necessary aggressively to demand that officers not arrest victims of domestic abuse unless they have clear and uncontradicted evidence that the law has been violated and that no justification or excuse for the violation exists.

One California community that has enacted a primary physical aggressor standard has in fact seen a drop in dual arrest rates. Once the primary physical aggressor standard was employed in San Diego, dual arrest rates significantly decreased. ${ }^{27}$ Proactive training in the police academies also helped to reduce the city's dual arrest rate to less than three percent of all doinestic violence arrests. ${ }^{278}$ Furthermore, police officers who made improper dual arrests saw their cases dismissed and were subject to the scrutiny of a Coordinated Community Response team. ${ }^{279}$ Together, these approaches led to a decrease in dual arrest rates. Following San Diego's approach, every county in California can achieve the true goals of a inandatory arrest statute and prevent the revictimization of battered women and their children by the criminal justice system.

\section{Benefits of Mandatory Arrest Outweigh Victim Autonomy}

Another argument advanced by opponents of mandatory arrest is that laws requiring certain police responses violate the autonomy of victims of domestic abuse. ${ }^{280}$ Victins, these advocates argue, not police officers and prosecutors, are in the best position to decide what action is in their best interests. ${ }^{281}$ Arrest may just further anger the batterer, yet the criminal justice system offers the victim no real protection from continued abuse. Consequently, advocates argue that paternalistic notions that the state knows what is best for women should be abandoned and battered women should be able to control the way law enforcement responds to domestic violence calls.

However, years of experience teach that this idea of victim "autonomy" really amounts to a wolf in sheep's clothing. Historically, the legal system has approached domestic violence by focusing on the victim, asking "'Why won't she press charges?' or 'Is she willing to prosecute?'"282 By placing the responsibility of charging and prosecuting on the victim, prosecutors increase the danger to victims and are

277. See infra Part V.

278. See Casey G. Gwinn \& Anne O'Dell, Stopping the Violence: The Role of the Police Officer and the Prosecutor, 20 W. ST. U. L. REv. 297, 314 (1993).

279. See id. For a detailed discussion of Coordinated Community Response teams, see infru Part $\mathrm{V}$.

280. See, e.g., Carol Wright, Comment, Immediate Arrest in Domestic Violence Situations: Mandate or Alternative, 14 CAP. U. L. REv. 243, 260 (1985).

281. See id.

282. Gwinn \& O'Dell, supra note 278 , at 310. 
forced to drop cases when these women feel they cannot participate in this manner. ${ }^{283}$ As a result, batterers remain free to reoffend.

After years of working with domestic abuse cases, prosecutors in San Diego learned that abusers intensified their abuse of victims once they discovered that the woman controlled the prosecution of their cases. ${ }^{284}$ Because batterers have such overwhelming control over their victims, and the system required victims to control the prosecution, batterers, in effect, were being given control over the disposition of their own criminal case. "The batterer's control over the victim is generally so complete that he was able to dictate whether she talked to the prosecutor, what she said, and whether she appeared in court."285

San Diego solved this problem by removing the control of the case from the victim and placing it with the state, where police officers and prosecutors get paid to enforce the law.

The victim of a crime is neither trained nor emotionally able to act in the role of cop or prosecutor. Once prosecutors and police officers stop asking victims whether they want to press charges, they quickly find that victims stop asking to press charges or drop charges. The victim is able to be the victim and address her pressing issues of safety for herself and her children and the system is able to focus on the one who broke the law. ${ }^{286}$

Prosecutors who remove the responsibility to prosecute from the victim's shoulders are seeing greater victim cooperation and higher conviction rates. Once judges understand that the victim is not the person who decided to prosecute the defendant, they lessen their hostility toward victims, whom they often regard as "wasting" the court's time. ${ }^{287}$ Soon, all the actors in the Coordinated Community Response team appropriately begin to shift their focus away from the victim's actions to the batterer's violent behavior. Finally, victims who are aware that they are not responsible for the prosecution of the defendant tend to become more cooperative. ${ }^{288}$ Although some victims will undoubtedly resent a system that may act in a fashion contrary to their wishes, reconceptualizing and treating domestic violence as a crime against the state will enhance the protection of all victims of domestic violence and provide a stronger deterrent to domestic abuse.

\footnotetext{
283. See id.

284. See id.

285. Id.

286. Id. at 310-11.

287. See id. at 311.

288. See id.
} 


\section{Mandatory Arrest Need Not Have a Discriminatory Impact on Racial Minorities, Gays and Lesbians}

\section{Countering Racial Discrimination}

One of the most compelling arguments against mandatory arrest is that it will increase the already discriminatory impact of the criminal justice system on men and women of color. Advocates fear that mandatory arrest policies will result in higher arrest rates for people of color than for whites. ${ }^{289}$ Advocates also fear that officers will improperly arrest women of color, either alone or as part of a dual arrest, under a mandatory arrest scheme. While there are currently no data available on dual arrests in minority households or the racial breakdown of women arrested in domestic violence incidents, data reported on minority arrest rates under mandatory arrest laws do not confirm advocates' suspicions.

Supporters of mandatory arrest expect that the law will actually decrease the amount of discrimination currently allowed in the purely discretionary system. ${ }^{290}$ Although domestic violence is equally prevalent in all racial and socio-economic groups, ${ }^{291}$ police officers are often reluctant to arrest middle- and upper-class white batterers, especially in small towns or rural locations where the officers know, or are friends with, the batterers. ${ }^{292}$ Mandating arrest is meant to ensure that race and class distinctions are not the basis for determining whether to make arrests in domestic violence cases. Under a mandatory arrest scheme, officers must consider specific, objective criteria when determining whether an arrest must be made.

Data reported from several states and cities with mandatory arrest schemes indicate that the laws are not having a discriminatory impact against men of color. In Wisconsin, records show that after the enactment of mandatory arrest, the percentages of white and minority domestic violence offenders who were arrested closely correlated to the state's population according to the 1980 census. ${ }^{293}$ Similar data from Iowa show that African-American men were not more likely than whites to be arrested under a mandatory arrest scheme. ${ }^{294}$ Furthermore, it was only after Duluth, Minnesota enacted a mandatory arrest law that its

289. See, e.g., Ruttenberg, supra note 254 , at 182-83.

290. See Buel, supra note 7, at 224.

291. See id.

292. See id.

293. See Zorza \& Woods, supra note 233, at 20. Although the data show the percentage of African-American offenders rose during 1990 to 1994, statistics on the percentage of these offenders who were arrested is not available for this time period. See OfFICE OF CRIME VICTIM SERvices, Wis. DeP'T OF JUSTICE, DOMESTIC ABUSE INCIDENT REPORT FOR 1990 AND 1991, at 9-13 (1993) [hereinafter 1990-91 REPORT]; 1992-93 REPORT, supra note 276, at 8-16.

294. See Zorza \& Woods, supra note 233, at 21. 
percentage of minority offenders began to approximate the city's minority population. ${ }^{295}$

Although the data indicate officers are not using the guise of mandatory arrest to discriminate against people of color, both women and men of color have legitimate reasons to distrust the criminal justice system in America, especially in California. Events such as the Rodney King beating by Los Angeles police officers and the beating of undocumented Mexicans by Riverside County sheriff's deputies expose how law enforcement officials in California routinely mistreat many men and women of color. ${ }^{296}$ In addition, there can be no doubt that women of color in general have fewer options and less assistance when attempting to escape their batterers. ${ }^{297}$ Victims of color are often forced to look for help from white, middle-class service organizations, whose staff does not speak their language or know their culture. ${ }^{298}$

Admittedly, there are no easy solutions to these complex societal problems. However, failing to arrest abusers does not solve these problems either. Rather, implementation of mandatory arrest laws, along with Coordinated Community Response teams, discussed in Part $\mathrm{V}$, must directly confront issues of discriminatory impact. All actors in the criminal justice system must receive considerable training on how to provide a culturally-sensitive response to victims of color. Community outreach, improved shelter services, and specialized counseling services must also be provided. Furthermore, law enforcement personnel, prosecutors, and judges must be held accountable for their actions toward minorities in domestic violence cases. This can, in part, be accomplished by a comprehensive data collection system, organized and run by the state, which will encompass all stages of the criminal justice process. The data should be compiled in an annual report, which includes both a statewide report and a breakdown of the data by county. This annual report should be disseminated to all members of a Coordinated Community Response team, as well as to the media and anyone else interested in the information. ${ }^{299}$ Close scrutiny by advocates

295. See id.

296. See Phil Hampton, Diversity in Deputies Eyed, PrEss-EnTERPRISE (Riverside), July 7, 1996, at A1; Roberto Rodriguez \& Patrisia Gonzales, Police Officers Must Be Held Accountable, FRESNo BeE, Sept. 18, 1995, at B5.

297. See Elizabeth M. Schneider, Particularity and Generality: Challenges of Feminist Theory and Practice in Work on Woman-Abuse, 67 N.Y.U. L. REv. 520, 532-34 (1992).

298. See Soraya M. Coley \& Joyce O. Beckett, Black Battered Women: Practice Issues, 69 Soc. CASEWORK 483, 483-84 (1988).

299. Although this task may seem arduous, thirty-five states and territories already collect data on domestic violence offenses. See National INST. of Justice, Domestic and Sexual Violence Data Collection: A Report to Congress Under the Violence Against Women act 11 (1996). For example, in Wisconsin, officers are required by law to fill out a form for every domestic violence incident. The data from this form are entered into a database and an annual report is 
and the media will help to ensure the accountability of officials and the quick solution of problems once they are detected.

Together, the Coordinated Community Response teams in each county can work to make sure mandatory arrest is not used as another tool to oppress and discriminate against people of color in California. Mandatory arrest represents the first framework where victims of abuse are adequately protected and batterers are punished, not for their race or ethnicity, but for their violation of the law.

\section{Countering Discrimination Against Gays and Lesbians}

Another important concern frequently overlooked in the debate over mandatory arrest laws is the potential for an adverse impact on gay and lesbian victims of domestic violence. Same-sex partner abuse has not been adequately recognized for several reasons, including pressure from some members of the gay and lesbian communities to keep the problem "within the community," the pervasiveness of homophobia in our culture, the failure of law enforcement and medical personnel to identify and report the abuse, a general lack of reporting by victims, and the absence of programs or services for gay and lesbian victims of domestic abuse. ${ }^{300}$

Although statistics are difficult to obtain, an estimated twenty-five to thirty percent of all lesbians and gay men in intimate relationships are victims of domestic violence. ${ }^{301}$ In 1987, the San Francisco Police Department received at least 100 calls every month involving gay and lesbian domestic abuse. ${ }^{302}$ Violence against gay and lesbian partners is just as serious and potentially lethal as heterosexual abuse. A San Francisco study revealed that both of the identified lesbians and four of the six identified gay men killed between 1991 and 1992 were murdered by their partners. ${ }^{303}$

Most battered gay men and lesbians, like most other victims of abuse, become extremely isolated as the fear of humiliation and the stigma of victimization compels their silence. ${ }^{304}$ Being gay in an openly homophobic culture compounds victims' reluctance to seek outside help. Furthermore, many lesbians and gay men cannot look to their families for help, because family members may be unaware of the

produced and disseminated. See generally 1990-91 REPORT, supra note 293; 1992-93 REPORT, supra note 276.

300. See Carla M. da Luz, A Legal and Social Comparison of Heterosexual and Same-Sex Domestic Violence: Similar Inadequacies in Legal Recognition and Response, 4 S. CAL. REV. L. \& WOMEN's STUd. 251, 268 (1994).

301. See Letellier, supra note 75 , at 16.

302. See ISLAND \& LETELLIER, supra note 185 , at 8.

303. See Letellier, supra note 75, at 16.

304. See id.; see also Robson, supra note 75, at 580-81. 
victim's sexual orientation, or, when they are aware, may have already ostracized the victim. ${ }^{305}$ While some lesbian victims may be able to seek assistance from existing shelters for heterosexual battered women, there are no shelters for battered gay men in the United States. ${ }^{306}$

Perhaps most importantly, many lesbians and gay men do not feel they can turn to the criminal justice system for help.

Calling the police, which is increasingly seen as an option for (white, middle-class) heterosexual women, remains unthinkable for most gay men given the widespread homophobia of many police departments. Indeed, according to recent studies of antigay violence, the median number of lesbians and gay men who were victimized by the police was $20 \% .{ }^{307}$

Gay and lesbian victims have been reluctant to call the police not only because of officer attitudes and abuse, ${ }^{308}$ but also because of the unwillingness of the gay and lesbian community to acknowledge the prevalence of same-sex partner abuse. The gay and lesbian communities have minimized and denied domestic violence within their ranks, largely out of fear that acknowledging the problem outside their communities will create additional negative images of the community and increase social homophobia. ${ }^{369}$

This lack of support and services, coupled with deserved mistrust of the police, means that the legislature must take several measures before a mandatory arrest law becomes effective in California. First, funding for shelters and other services for gay and lesbian victims must be statutorily mandated. Second, and perhaps most important, every actor within the criminal justice system must receive significant training on the prevalence and dynamics of abuse within gay and lesbian relationships, as well as other cultural dynamics affecting the community.

Third, all actors within the criminal justice system, particularly law enforcement officers, should receive specific training on how to carry out the primary physical aggressor standard when investigating an incident of gay or lesbian domestic abuse. This is especially important because domestic abuse among lesbian and gay partners is frequently mislabeled as mutual abuse. ${ }^{310}$ Police officers and others often assume that because both partners are the same gender and may

305. See Letellier, supra note 75 , at 18.

306. See id.

307. Id.

308. In one study, police officers ranked as the third most common perpetrators of anti-lesbian and anti-gay violence. See Gay \& Lesbian Stats: A Pocket Guide of Facts and Figures 70 71 (Bennett L. Singer \& David Deschamps eds., 1994).

309. See ISLAND \& LETELLIER, supra note 185, at 37; da Luz, supra note 300, at 269.

310. See ISLAND \& LETELLIER, supra note 185, at 16-17; Claire M. Renzetti, Violence in Lesbian Relationships: A Preliminary Analysis of Causal Factors, 3 J. INTERPERSONAL VIOLENCE 381, 397 (1988). 
be approximately the same size, each is equally responsible for the violence. ${ }^{311}$ This assumption, however, is unfounded. This so-called "Boxing Ring" myth stems from society's unwillingness to look at violence between partners of the same sex, especially when they are men, as an abusive situation where one person is clearly the victim. ${ }^{312}$ Consequently, officers and others must understand the realities of abuse in these relationships to enforce properly a mandatory arrest law enacted to protect all victims of domestic violence. Training on how to identify the primary physical aggressor in incidents of gay and lesbian domestic violence is another crucial element in the mandatory arrest scheme.

Finally, the state must keep detailed statistics on every domestic violence call logged with law enforcement officers in which sexual orientation and relationship of the parties is a category of documentation. ${ }^{313}$ Every victim advocate must maintain a vigilant watch over this data and work with training agencies and others to ensure that victims of same-sex domestic violence are not revictimized by the criminal justice system.

\section{E. Measures Can Be Taken to Minimize the Negative Impact of Mandatory Arrest on Undocumented Battered Women}

A final and extremely significant concern often expressed by advocates of battered women, especially in California, is the potentially adverse affect a mandatory arrest law could have on undocumented women in the state. When immigrant or refugee women are victims of domestic violence, partner abuse further complicates an already complex web of issues formed at the intersection of race, gender, socioeconomic, and immigrant status. ${ }^{314}$

First, immigrant women may not understand that domestic abuse is a criminal act that can be punished in this country. ${ }^{315}$ Of those battered immigrant women who are aware of the illegality of their abuser's conduct, many may not be aware that there are community resources available to help them. Furthermore, immigrant victims may be unfamiliar with how to access these resources, let alone how to navigate the complex U.S. legal system. ${ }^{316}$ In many counties in California, women may

311. See Letellier, supra note 75 , at 18.

312. See 1sLAND \& LETELLIER, supra note 185, at 16-17.

313. Although this data should be used for statistical purposes, the names of the parties should be kept confidential.

314. See Deeana L. Jang, Caught in a Web: Immigrant Women and Domestic Violence, 1994 Nat'L Clearinghouse 397, 397.

315. See Deborah Weissman, Protecting the Battered Immigrant Woman, FLA. B.J., Oct. 1994, at 81, 81-82.

316. See id. 
be unable to locate a bilingual advocate or attorney. Often, women who do not speak English are considered improper candidates for support by domestic violence agencies that lack multi-lingual staff and interpreters. ${ }^{317}$

A mandatory arrest scheme raises further problems for battered immigrant women who are usually afraid to come into contact with the police. An undocumented battered woman may be even more reluctant to call the police under a mandatory arrest scheme if she fears the call will lead to the deportation of the family's breadwinner.

If she is from a country where the police are repressive, it is difficult for her to have anything but terror of the police. She may fear that if the batterer is arrested he will refuse to cooperate with the immigration process on her behalf, resulting in her deportation. Often, she will be economically dependent on her partner. She is likely to be isolated due to intimidation by her husband's threats to call INS and her own fear of deportation. Like most survivors of domestic violence, she may hide the problem because of fear, shame, and denial, or because she does not know what to do. ${ }^{318}$

These fears of immigrant battered women will be further exacerbated if Proposition 187 is allowed to take effect in California. ${ }^{319}$ Proposition 187 was a statewide referendum passed by the voters of California on November 8,1994 . The referendum, along with denying social services to undocumented persons, requires all law enforcement agencies to "fully cooperate" with the United States Immigration and Naturalization Service (INS) when auy person who is arrested is suspected of unlawfully residing in the United States. ${ }^{320}$ Full cooperation is later defined to require that law enforcement officers attempt to verify the legal status of every suspect arrested and report any undocumented immigrants to the INS. ${ }^{321}$ Although Proposition 187 has already been ruled unconstitutional by at least one United States District Court ${ }^{322}$ and may never take effect, the anti-immigrant sentiments among many in California lend credence to battered immigrant women's fears of deportation when they come in contact with the criminal justice system.

Much effort and sensitivity will be needed to ensure that mandatory arrest does not have a disproportionate impact on immigrant battered

317. See id.

318. Id. at 82.

319. See League of United Latin Am. Citizens v. Wilson, 908 F. Supp. 755 (C.D. Cal. 1995) (finding that several portions of Proposition 187 were preempted by federal law and the federal Constitution).

320. See Cal. Penal Code $\S 834 b(a)$ (West Supp. 1997) (added by Proposition 187).

321. See id.

322. See League of United Latin Am. Citizens, 908 F. Supp. at 786-87. 
women. The primary physical aggressor standard, accurately applied, should assist in protecting victims of domestic abuse from being improperly reported to INS because, under Proposition 187, officers are required to report only arrested offenders suspected of being undocumented. Furthermore, advocates must utilize the recent changes in immigration law that enable battered women to achieve citizenship status without depending on their abusive partner's sponsorship or assistance. ${ }^{323}$ Finally, support for all battered immigrant women must be made available, including services with staffs who speak the victims' languages and are familiar with their customs.

Ultimately, we must sensitize law enforcement officers to the concerns of battered immigrant women. Assuming that contact with the police is inevitable for many battered immigrant women, we must increase assistance to them by easing their documentation process where possible, assisting them iu becoming economically self-sufficient, and teaching them to lead violence-free lives. Improving these resources will provide much greater protection and safety than simply denying immigrant battered women police protection because of the potential repercussions.

\section{Providing Solutions: Toward a Comprehensive Coordinated COMMUNITY RESPONSE TO DOMESTIC VIOLENCE}

While a mandatory arrest statute is a crucial part of au effective response to domestic violence, such a statute, by itself, cannot eradicate the epidemic of abuse plaguing California. Domestic abuse advocates have long argued that arrest alone would not sufficiently deter recurring abuse. ${ }^{324}$ In fact, advocates have never viewed mandatory arrest laws as the ultimate solution to the epidemic of domestic violence. Instead, they see them as the best vehicle for moving domestic violence cases into the criminal justice system and for communicating to society that domestic abuse is a crime against the state..$^{325}$

Consequently, mandatory arrest must be coupled with strong prosecution and sentencing. Each of the components of the criminal justice system must cooperate in a comprehensive effort to effectively confront domestic violence in California. Thus, arrest must be viewed as just one factor in a multi-faceted Coordinated Community Response (CCR) to domestic violence. While a CCR entails arresting, charging,

323. See Weissman, supra note 315, at 82-83; Felicia E. Franco, Unconditional Safety for Conditional Immigrant Women, 11 BeRKELEY WOMEN's L.J. 99, 118-20 (1996) (explaining the benefits of the newly enacted self-petitioning system for battered immigrant women).

324. See Zorza \& Woods, supra note 233 , at 33-35.

325. See id. 
convicting, and sentencing abusers, it also includes providing community education and training along with counseling programs for victims, batterers, and their children.

\section{A. The Central Role of Prosecution}

Actors within the criminal justice system now recognize that it takes more than a couple of days in jail to change permanently the dynamics of power and control that define an abusive relationship. ${ }^{326}$ Years of learning to use violence to control one's partner cannot be undone by a couple of hours behind bars. Although an arrest provides victims with a temporary respite to reflect and to achieve safety, it does not ensure that the perpetrator will be charged, let alone prosecuted. Consequently, prosecutors, who make these important decisions, often determine how the criminal justice system ultimately will treat domestic violence.

Historically, prosecutors have refused to file charges in domestic violence cases if they did not have the complete cooperation of the victim. ${ }^{327}$ Even when a victim started off "cooperative," prosecutors usually dismissed the case if the victim became uncooperative during the course of the proceedings. ${ }^{328}$ Police reports were generally short and incomplete. Police often failed to take witness statements and photographs at the scene of the crime. ${ }^{329}$

Officers making efforts to arrest in domestic violence incidents became frustrated by the number of defendants back in their homes before the officer could complete a report on the incident. ${ }^{330}$ Although the same offenders were arrested over and over again, they were rarely prosecuted. Even cases that survived the charging stage were generally plea-bargained for a lesser charge of disturbing the peace or creating a public nuisance, or dismissed if the victim recanted her story. This inadequate method of handling domestic abuse cases quickly led to high levels of police "burnout, frustration, and victim-blaming."

While many police departments and district attorney's offices in California and around the United States still operate in this fashion, ${ }^{332}$

326. See Gwinn \& O'Dell, supra note 278 , at 315-17.

327. See, e.g., id. at 299.

328. See, e.g., id.

329. See, e.g., id.

330. See, e.g., id.

331. Id.

332. In one study tracking 140 domestic abuse arrests made across the country on June 18, 1995, seventy-one, or almost $51 \%$ of the cases, were dismissed. See Alison Frankel, National Survey Yields Depressing Results, ReCORDER, June 3, 1996, at 11. For those defendants who were convicted, jail sentences were rare. Most received only a year or two of probation, "despite having inflicted injuries that ranged from black eyes and bloody lips to burns and stab wounds." Id.; see also National inst. of Justice, The Criminalization of Domestic Violence: Promises and 
several counties have made tremendous efforts to change their systemic response to domestic violence. ${ }^{333}$ Among the most successful in the country is San Diego County, where the City Attorney's Office handles misdemeanor cases and the District Attorney's Office handles all the county's felonies.

In 1986, prosecutors, police officers, advocates, and service providers in San Diego began meeting to address their frustrations and to discuss and reformulate policies on handling domestic abuse cases. ${ }^{334}$ In August of 1986, the City Attorney's Office adopted a host of new policies regarding the handling of misdemeanor domestic violence cases. One such change was that the prosecutor-and not the victim-would make the decision whether to file charges against the perpetrator. In addition, no cases would be dropped, even when the victim would not cooperate, and no charges would be reduced as part of a plea-bargain. ${ }^{335}$

These new policies received much attention after the office refused to dismiss charges against San Diego Municipal Judge Joseph Davis, who was arrested for beating his pregnant girlfriend, even after his girlfriend recanted and disappeared. ${ }^{336}$ Although the case was dismissed after the jury deadlocked, and the office was criticized for its bold new strategies, the City Attorney's Office and the Police Department became more committed than ever to fighting domestic violence in San Diego. ${ }^{337}$ Prosecutors, for the first time, learned how to try a misdemeanor domestic violence case without victim cooperation. Over the next six months, the City Attorney's Office won fifteen of the seventeen domestic abuse cases they tried without cooperation from the victim. ${ }^{338}$

Over the next six years, the City Attorney's Office and the San Diego Police Department organized a county-wide task force; created, refined, and revised policies and protocols for domestic violence cases; organized trainings and media campaigns; and established education programs within the county's school system. ${ }^{339}$ The Domestic Violence Units of the San Diego Police Department and the City Attorney's

Limirs 15 (1995) (reporting various studies which found that less than ten percent of misdemeanor domestic violence cases are prosecuted).

333. See, e.g., Elena Salzman, The Quincy District Court Domestic Violence Prevention Program: A Model Legal Framework for Domestic Violence Intervention, 74 B.U. L. REv. 329, 33853 (1994) (discussing Quiney, Massachusetts' innovative program for handling domestic violence cases).

334. See Gwinn \& O'Dell, supra note 278, at 299-300.

335. See id. at 300. The Los Angeles City Attomey's Office has maintained a similar "no drop" policy since 1978. See Alana Bowman, A Matter of Justice: Overcoming Juror Bias in Prosecutions of Batterers Through Expert Witness Testimony of the Common Experiences of Battered Women, $2 \mathrm{~S}$. CAL. Rev. L. \& WOMEN'S STUd. 219, 225 (1992).

336. See Gwinn \& O'Dell, supra note 278 , at $300-02$.

337. See id. at 303.

338. See id.

339. See id. 
Office grew from staffs of one person each to the two largest domestic violence units in the country. With a full-time and volunteer staff of thirty, the City Attorney's Domestic Violence Unit is the largest specialized prosecution unit for misdemeanor domestic violence cases in America. ${ }^{340}$ In addition, twenty detectives, three sergeants, and eight volunteers in the San Diego Police Department investigate more than 1,200 domestic violence cases each month. ${ }^{341}$

The best measure of the task force's efforts, however, is its impact on reducing domestic violence homicides in the county. In 1986, almost one-third of all murders in San Diego were domestic violence homicides. ${ }^{342}$ Police were contacted for prior domestic abuse incidents involving the same couple an average of five times before one of the parties murdered the other. ${ }^{343}$ Since 1985 , the county has seen a reduction in the domestic violence homicide rate of nearly seventy percent. ${ }^{344}$ The Domestic Violence Units have also seen a large reduction in their re-arrest and re-prosecution rates for abusers who were prosecuted and who participated in long-term batterer's treatment programs. ${ }^{345}$ While almost sixty percent of their cases involve victims who have either disappeared or refuse to cooperate, the City Attorney's Office obtains convictions in eighty-eight percent of all misdemeanor domestic violence cases. $^{346}$

San Diego's experience demonstrates that a comprehensive program integrating mandatory arrest, no-drop prosecution, and other remedies and services into a single, Coordinated Community Response can send a strong message to batterers, victims and the entire community that domestic abuse will no longer be tolerated. San Diego's Coordinated Commuuity Response provides an excellent model for every county in California to replicate.

\section{B. Coordinated Community Response Teams}

As San Diego's experience illustrates, a Coordinated Community Response (CCR) involves more than group meetings-it involves an entire process. It is "the process of bringing domestic abuse victims, their advocates, key players in the criminal justice system and members of the

340. See id. at $299,304$.

341. See id. at 297-98.

342. See id. at 299.

343. See id.

344. See Stansky, supra note 258, at 50. Similarly, no woman in Quincy, Massachusetts was murdercd in a domestic violence incident during the first eight years of the Quincy program's operation. See Salzman, supra note 333 , at 335.

345. See Gwinn \& O'Dell, supra note 278, at 304; see also Hanna, supra note 123, at 1864-65 (reporting that jurisdictions committing significant resources to domestic violence prosecution are seeing higher rates of conviction and lower rates of recidivism).

346. See id. 
community together to develop strategies, policies and procedures" that focus on the dynamics and prevalence of domestic violence and "establish ways by which the community will take responsibility to end the abuse."347

The three primary goals of a CCR are to maximize safety and protection for victims, to hold batterers accountable for their actions, and to analyze and eradicate the cultural roots of domestic violence. ${ }^{348}$ CCRs aim to reform community systems by creating a consistent and definite response to incidents of domestic violence.

Intervention strives to put the community-its agents, its protection and its support-between the victim and the abuser. Its goal is to take the responsibility for imposing legal sanctions on the abuser, not to focus on what the victim might be believed to have done to create, provoke or deserve the violence. While holding the abuser accountable, [a CCR] affords that person the opportunity to change by providing resources and tools in the form of counseling/education programs. A CC $[R]$ project does not form another layer of systems; rather, it is an effort to bring the existing systems together to mutually address issues of domestic abuse. 349

Through such strategies, CCRs, such as the Duluth Domestic Abuse Intervention Project, are changing their communities' perceptions about domestic violence. Duluth's program has yielded higher conviction rates for misdemeanor domestic violence crimes and reduced recidivism rates among domestic abuse offenders. ${ }^{350}$

Such programs are successful because they have been able to bring together all the key actors needed for an effective CCR. The central personnel who are essential to every county CCR team include the chief of police of every major city in the county, the sheriff, the district attorney, the chief judge of the relevant judicial district, the family court commissioner, a representative from a victim advocates' program, a representative from a batterers' treatment program, a probation officer and a parole officer, an advocate from a relevant children's program, representatives from legal services agencies, and survivors of domestic violence. ${ }^{351}$ These key players meet to measure whether their goals are being accomplished and what else they must do to achieve these goals.

347. See Wisconsin Equal Justice Task Force, Domestic Abuse Subcommittee Report 182 (1991) [hereinafter EQUAL JUSTICE]. For a different but related approach, see Jeffrey L.

Edleson, Coordinated Community Responses, in Woman BatTering, supra note 8, at 203 (discussing Community Intervention Projects).

348. See EQUAL JUSTICE, supra note 347, at 182.

349. Id. at 182-83.

350. See Welch, supra note 193, at 1151-52 (explaining the success of the Duluth Domestic Ahuse Intervention Project, one of the first Coordinated Community Responses in the country).

351. See EQUAL JUSTICE, supra note 347, at 183. 
Each person must be an active member of the CCR team, as each piece of this puzzle is needed to address the problem of domestic abuse. It is also crucial that the members of the team be people with the authority to develop and implement policies affecting victims of domestic violence. Team members should also have knowledge of how other successful programs have dealt with similar issues in the past. ${ }^{352}$

Each CCR should meet regularly; monthly meetings are suggested. At these scheduled meetings, members discuss problems and frustrations they are having withm their own organizations and with others. As a team, they discuss how best to address these concerns. Members also discuss recent issues surrounding domestic violence that have come to the forefront in their area. They address solutions to these problems, which may include developing new methods to improve communication and cooperation with other agencies, proposals for new education and trainimg programs, requests for additional funding, or proposals for new legislation. In general, the CCR should function as the primary organization which monitors and works to improve the community's systemic response to domestic abuse and as the key source for policy development in the area.

While many Califoruia communities have already established some type of CCR, most of these teams have not yet solidified into the productive network needed for an effective community response. ${ }^{353}$ California must renew current CCRs by providing each of the fifty-eight teams with adequate resources and materials. The state must give CCRs the funding and support necessary to take the initiative in eliminating domestic abuse. In addition, CCRs need to establish better relationships with the media to improve publicity and awareness of their efforts. As demonstrated by the experiences of counties such as San Diego and Dane County, Wisconsin, ${ }^{354}$ these strategies can work to bring about significant change and reduce the occurrence and severity of domestic violence in California.

\section{CONCLUSION}

Legislative reform is necessary to provide adequate protection to all victims of domestic violence in California. California must allow warrantless arrest for all misdemeanor domestic violence assaults. It must also enact a mandatory arrest law for the primary physical aggressor in

352. See id. at 183-84 (explaining that members of a CCR should be aware of successful policies and programs).

353. See, e.g., Deborah Yaffe, A Losing Battle, ReCorder, June 3, 1996, at 1 (discussing Alameda County's recent development of a county-wide domestic violence council).

354. See Gwinn \& O'Dell, supra note 278, at 305-07 (citing the success of the Coordinated Community Responses in San Diego and Dane County, Wisconsin). 
a domestic violence assault. Although many valid concerns exist surrounding the effects of a mandatory arrest scheme, proper police training, statutory language directing police to arrest only the primary physical aggressor, and close public scrutiny can alleviate many of these problems. Mandatory arrest will provide proper punishment for batterers, enhance awareness of domestic abuse in society in general, and, most importantly, help victims of domestic abuse to obtain safety and establish lives free from the violent attacks of their loved ones.

As many battered women without resources have noted, victims of domestic abuse call the police for help because they have nowhere else to turn. Instead of forcing victims to obtain civil restraining orders or to "press charges" against their batterers before the criminal justice system takes their cries for help seriously, the criminal justice system must treat every instance of domestic violence for what it truly is: a dangerous crime committed against the state. Only after we take the focus off of victims by making domestic violence a crime against the state and establish Coordinated Community Response teams to make changes in the criminal justice system's response to domestic abuse in our society will a mandatory arrest scheme be effective. Once these changes are made, however, mandatory arrest will provide the best protection for all victims of domestic abuse in California. 